$12-1-2014$

\title{
Judge Posner, Judge Wilkinson, and Judicial Critique of Constitutional Theory
}

Marc O. DeGirolami

St. John's University School of Law

Kevin C. Walsh

University of Richmond School of Law

Follow this and additional works at: https://scholarship.law.nd.edu/ndlr

Part of the Constitutional Law Commons

\section{Recommended Citation}

90 Notre Dame L. Rev. 633 (2014)

This Article is brought to you for free and open access by the Notre Dame Law Review at NDLScholarship. It has been accepted for inclusion in Notre Dame Law Review by an authorized editor of NDLScholarship. For more information, please contact lawdr@nd.edu. 


\title{
JUDGE POSNER, JUDGE WILKINSON, AND JUDICIAL CRITIQUE OF CONSTITUTIONAL THEORY
}

\author{
Marc O. DeGirolami Ẽ Kevin C. Walsh*
}

\begin{abstract}
Judge Richard Posner's well-known view is that constitutional theory is useless. And Judge J. Harvie Wilkinson III has lambasted constitutional theory for the way in which its "cosmic" aspirations threaten democratic self-governance. Many other judges hold similar views. And yet both Posner and Wilkinson-in the popular press, in law review articles, and in books-have advocated what appear to be their own theories of how to judge in constitutional cases. Judicial pragmatism for Posner and judicial restraint for Wilkinson seem to be substitutes for originalism, living constitutionalism, political process theory, and so on. But both Posner and Wilkinson also deny that they are offering a theory at all. This is puzzling. How do these judges simultaneously reject constitutional theory yet seemingly replace it with theories of their own?

This Article answers that question-a question that must be answered in order to understand the present-day relationship between constitutional theory and constitutional adjudication. The perspectives of Judge Posner and Judge Wilkinson are particularly valuable because they have not only decided hundreds of constitutional cases but have also written extensively about constitutional theory. Drawing on a close reading of revealing slices of both their extrajudicial writing and their judicial opinions in constitutional cases, this Article makes three contributions. First, it brings to light agreements between Posner and Wilkinson that run far deeper than the heralded differences between them and that stem from their situated understanding of their judicial role. Second, it exposes the limited influence of judicial pragmatism and judicial restraint on these judges' own constitutional jurisprudence even in those cases where one might expect constitutional theory to exert maximal influence. Third, it explains how judicial pragmatism
\end{abstract}

(C) 2014 Marc O. DeGirolami and Kevin C. Walsh. Individuals and nonprofit institutions may reproduce and distribute copies of this Article in any format at or below cost, for educational purposes, so long as each copy identifies the author, provides a citation to the Notre Dame Law Review, and includes this provision in the copyright notice.

* Associate Professor, St. John's University School of Law, and Associate Professor, University of Richmond School of Law, respectively. We thank Jeremy Blumenthal, Samuel Bray, Richard Fallon, James Gibson, Philip Hamburger, Scott Hemphill, Orin Kerr, Randy Kozel, Corinna Lain, Joseph Landau, Allison Orr Larsen, Julian Davis Mortenson, Jeffrey Pojanowski, Richard Posner, Jack Preis, Jeremy Sheff, Adam White, and Adam Zimmerman for helpful comments on earlier drafts. We also thank Tracy Hermann, Alec Kast and Leah Stiegler for indispensable assistance with research. This Article benefited from presentations at the BYU ICLARS Conference, the Fordham Law School Junior Faculty Forum, the St. John's Law School Faculty Workshop, and the Virginia Junior Faculty Forum. 
and judicial restraint are best understood not as constitutional theories but as descriptions of judicial dispositions-character traits that pertain to judicial excellence-that can and should be criticized on their own terms.

\section{INTRODUCTION}

"The most unexceptionable source of collateral interpretation is from the practical exposition of the government itself in its various departments upon particular questions discussed, and settled upon their own single merits. . . . How light, compared with these means of instruction, are the private lucubrations of the closet, or the retired speculations of ingenious minds, intent on theory, or general views, and unused to encounter a practical difficulty at every step!"

- Joseph Story, Commentaries on the Constitution of the United States (1833)

Not long ago, Chief Justice John Roberts dismissed academic legal writing as "abstract" and "philosophical" in ways unhelpful to the judiciary and "legal practice." 1 His comments elicited a flurry of responses, but the discussion rapidly exhausted itself. The reason may well be that the tension he highlighted has an enduringly familiar quality. There has always been a gap between theoretical and practical perspectives on law in the United States and the Anglo-American legal tradition more broadly. A tradition of circumspect separation stretches back at least as far as the anxious misgivings of medieval English lawyers and judges with respect to "academic generalizations about natural law" and its role in adjudication. ${ }^{2}$

Today, the distance between judges and academic theorists is particularly pronounced in constitutional law. Judge Richard Posner, for example, has argued that constitutional theory is a waste of time, ideologically motivated, and useless to judges. ${ }^{3}$ And Judge J. Harvie Wilkinson III has argued that all of the "cosmic" constitutional theories on offer now are fundamentally flawed and threaten democratic self-governance. ${ }^{4}$ Yet both Posner and Wilkinson-in the popular press, in law review articles, and in books-have advocated their own distinctive approaches to constitutional adjudication. Judicial pragmatism for Posner and judicial restraint for Wilkinson have been taken by many to be the same kind of theory that each criticizes. But both Posner and Wilkinson deny that they are offering a theory at all. Posner has gone even further, invoking Samuel Johnson's old aphorism in likening a

1 A Conversation with Chief Justice Roberts at 29:00 (C-SPAN broadcast June 25, 2011), available at http://www.c-span.org/video/?300203-1/conversation-chief-justice-roberts.

2 Philip Hamburger, Law and Judicial Duty 27 (2008) (describing the roots of the friction between the openness of learned law to extralegal sources and the constrained traditions of common law judging); see also Gerald J. Postema, Classical Common Law Jurisprudence (Part I), 2 Oxford U. Commonwealth L.J. 155, 157 (2002) ("Classical common law jurisprudence was articulated by reflective but politically engaged jurists in the 17 th century. ... [T] hey were legal practitioners, not detached observers.").

3 See generally Richard A. Posner, Against Constitutional Theory, 73 N.Y.U. L. Rev. 1 (1998) (criticizing constitutional theories of interpretation).

4 See generally J. Harvie Wilkinson III, Cosmic Constitutional Theory: Why Americans Are Losing Their Inalienable Right to Self-Governance (2012). 
judge who writes about constitutional law to "a dog walking on his hind legs: The wonder is not that it is done well but that it is done at all." ${ }^{5}$ This is all puzzling. How do these judges simultaneously reject constitutional theory yet purport to replace it with approaches like judicial pragmatism and judicial restraint that seem to be theories of their own? ${ }^{6}$

This Article answers this question through a close reading of revealing slices of the extrajudicial and judicial output of these two distinguished federal judges. These judges' writings hold particular promise for understanding the relationship of constitutional theory and constitutional adjudication, for Judge Posner and Judge Wilkinson have contributed to both. Both are former law professors at top institutions-Posner at the University of Chicago School of Law, where he remains a senior lecturer, and Wilkinson at the University of Virginia School of Law. And they are prolific legal scholars. Each has produced several books, dozens of articles, and a great deal of other writing, and each has written specifically and extensively on constitutional theory. Both have also authored scores of opinions on constitutional questions across their careers, so that one can usefully compare their judicial and extrajudicial writing on constitutional theory and constitutional law ("that least disciplined area of American law," as Posner has put it). ${ }^{7}$ Having worn judicial robes and academic gowns, they are doubly qualified to address constitutional law from the perspectives of both judging and theory.

It is also illuminating to examine these two thinkers together because Judge Posner and Judge Wilkinson sometimes treat each other as antagonists-even foils. Posner is a pragmatist; Wilkinson is a legalist. Posner emphasizes the importance of economics, empirical inquiry, and reliance on social science in the context of an overarching project to "overcome" law; ${ }^{8}$ Wilkinson emphasizes legal materials and judicial restraint in the context of stressing the value of the rule of and under law. ${ }^{9}$ Posner criticizes judges who mouth platitudes about the determinacy of doctrine; Wilkinson criticizes judges who are in the grips of theoretical or sociological abstractions and who feel comparatively unconstrained by doctrine. The two men appear not merely to disagree but to come at adjudication guided by directly opposing theories.

5 Richard A. Posner, Justice Breyer Throws Down the Gauntlet, 115 Yale L.J. 1699, 1699 (2006) (reviewing Stephen Breyer, Active Liberty (2005)).

6 Theories, after all, are simply sets of general and abstract ideas that either describe or guide a practice-in this case, the practice of judging in constitutional cases. See, e.g., Bernard Williams, Ethics and the Limits of Philosophy 116-17 (1985) ("Theory looks characteristically for considerations that are very general and have as little distinctive content as possible, because it is trying to systematize and because it wants to represent as many reasons as possible as applications of other reasons."); Jeffrie G. Murphy, Kant on Theory and Practice, in Theory and Practice: NOMOS XXXVII 49 (Ian Shapiro \& Judith Wagner DeCew eds., 1995).

7 Richard A. Posner, How Judges Think 237 (2008).

8 Richard A. Posner, Overcoming Law (1995).

9 Wilkinson, supra note 4. 
Yet beneath these disagreements, there is a deeper and more fundamental harmony of perspective that unites them. This Article excavates and describes that perspective, one that is particularly salient given their doubly intermediate position between the Supreme Court and district courts, and between academic and judicial discourse. This perspective leads Judge Posner and Judge Wilkinson to criticize constitutional theories that ignore or marginalize the relationship between constitutional interpretation and judicial role in constitutional adjudication. This is the critical dimension of their writing about constitutional theory. But their writing as judges also reveals a constructive dimension: more than a constitutional theory, what judges bring to constitutional adjudication is a distinctive perspective that arises out of their particular office within the judicial hierarchy. The influence of constitutional theory is less powerful than, and never abstracted from, factors relating to judicial role. The judges' extrajudicial "theory disclaimers" should therefore be accepted. Rather than as theories, judicial pragmatism and judicial restraint are best understood as dispositions that each judge advocates toward the activity of judging in light of their particular role in the federal judicial hierarchy.

This Article makes three contributions: first, it brings to light the fundamental agreements in these judges' writing about constitutional theory, agreements that run far deeper than their heralded differences and that stem from their shared, situated understanding of their judicial role; second, it exposes the limited influence of judicial pragmatism and judicial restraint on these judges' own constitutional jurisprudence even in those cases where one might expect constitutional theory to exert maximal influence; and third, it explains how judicial pragmatism and judicial restraint are best understood not as constitutional theories but as descriptions of judicial dispositions-character traits that pertain to judicial excellence-which can and should be criticized on their own terms. Our project in this Article is limited: to identify a distinctive perspective in the work of two prominent American federal judges and to pursue certain associated insights into constitutional adjudication. Yet we examine Judges Posner and Wilkinson not because there is something that binds the thought of these two judges as a unique pair, but because exploring what binds them lays bare a larger perspective pertaining to the judicial office that they hold. When they sit as judges, they are not theorists on the bench, but judges-and they are working from within a practice that generates a distinctive perspective on constitutional adjudication.

Insight into this perspective emerges from careful consideration of the different types of writing published by these two judge-theorists. Part I of this Article- “The Judge at Rest: Extrajudicial Writing”-explores a selection of Judge Posner's and Judge Wilkinson's respective extrajudicial writings about interpretive method and judicial role in constitutional cases. In these writings, the positions staked out by the judges seem most divergent. Part II"The Judge at Work: Judicial Writing"-is the heart of the Article. It examines paired sets of their judicial opinions in three constitutional contexts: 
gun possession for self-defense outside the home, partial-birth abortion, and perceived official favoritism of Christianity. And it assesses the relationship of the judges' extrajudicial writing to the ways in which they justify their decisions in their judicial writing. Part III explains that it is more helpful and more accurate to understand judicial pragmatism and judicial restraint as descriptions of desirable judicial dispositions. Once so understood, it is possible to criticize judicial pragmatism and judicial restraint as portraits of excellence in constitutional adjudication. It is also possible to offer alternate understandings of judicial excellence, and Part III does so by considering the example of Judge Henry Friendly. By clarifying the nature of judicial pragmatism and restraint, and by critiquing them from the inside and on their own terms, this Article sheds new light on the enduring distance between judges and legal academics in their respective approaches to constitutional adjudication.

In the end, there is an important truth in Chief Justice Roberts's observations about the separation of the bench and the academy. A judge, as Roberts put it in more recent remarks, possesses a particular perspective, outlook, and set of concerns-a distinctive "way of looking at issues." 10 That perspective influences a judge's writing on and off the bench. And it suggests that when Judges Posner and Wilkinson write about constitutional theory, they are not dogs walking on their hind legs, though they are often made to look that way by academic critics who have misunderstood their projects, just as they at times misunderstand the projects of constitutional theorists. The judges and the theorists are talking and walking past one another. It is only by recognizing that their projects are distinctive, and by resisting the impulse to merge them, that the two can reach a mutual understanding.

\section{The Judge at Rest: Extrajudicial Writing}

This Part explores Judge Posner's and Judge Wilkinson's respective extrajudicial writing - their writing as judges "at rest" - that is, while still very much judges but not engaged in their official judicial work. ${ }^{11}$ What appears to emerge is mutual intellectual antagonism. Yet beneath this layer of disagreement, a more complex and extensive substratum of commonalities exists. These commonalities pertain to the judges' shift from theory to disposition as a guide to the practice of constitutional adjudication.

Judge Wilkinson and Judge Posner object to prevailing academic methods of constitutional theorizing that marginalize judicial role even as they purport to offer prescriptions for constitutional adjudication. This overarching critique often is manifested as a specific objection against constitutional

10 See Linda Greenhouse, Justices on the Job, N.Y. Times (July 24, 2013, 9:00 PM), http:// opinionator.blogs.nytimes.com/2013/07/24/justices-on-the-job/?_php=true\&_type=blogs \&_php=true\&_type=blogs\&_r=1 (reporting Chief Justice Roberts's remarks at the June 2013 Fourth Circuit Judicial Conference).

11 The article does not aim at a comprehensive intellectual history. The selections are intended to highlight specific features of each judge's writing that best reveal how each has articulated his critique of constitutional theory. 
theories that proceed from the "top-down"-that is, in such a way that principles outside the law (often derived from academic moral or political philosophy) are said to control constitutional adjudication. ${ }^{12}$ It is also manifested in a criticism of constitutional theories that demand thoroughgoing interpretive consistency by scrupulous adherence to the particular principles or methods they espouse, without allowing space for the legitimate exercise of judicial discretion.

\section{A. Posner's Judicial Pragmatism at Rest}

Judge Posner's most recent in-depth writing about constitutional theory appears in two chapters of his book, Reflections on Judging. Chapter six concerns judicial restraint, while chapter seven discusses theories of interpretation. Posner distinguishes judicial restraint from theories of constitutional interpretation on the ground that judicial restraint does not purport to provide a single right answer to questions of constitutional interpretation. Posner surveys the views of various influential apostles of judicial restraint, dubbed "Thayerians" because of their genealogical connection to the form of judicial restraint first advanced by James Bradley Thayer. And he concludes that none of them (Oliver Wendell Holmes, Louis Brandeis, Felix Frankfurter, and Alexander Bickel) "had any idea how legal analysis would yield an answer to a question arising under one of the many vague or archaic provisions of the Constitution." 13 This makes sense, Posner explains, because if a Thayerian judge actually does have a theory that supplies these answers, "he will feel lawless in failing to apply it." ${ }^{4}$ After all, the whole point of a constitutional theory, Posner says, is to generate right answers to cases:

Modern constitutional theories-whether Bork's or Scalia's originalism, or Ely's representation reinforcement, or Breyer's active liberty, or the Constitution as common law, or the living Constitution, or the unwritten Constitution ...., or the invisible Constitution, or living originalism, or the moral reading of the Constitution, or libertarianism, or the Constitution in exile, or anything else-are designed to tell judges, particularly Supreme Court Justices, how to decide cases correctly rather than merely sensibly or prudently. ${ }^{15}$

In his chapters on judicial restraint and constitutional theory, Posner describes the various approaches to constitutional adjudication he examines as "coping strategies for appellate judges" 16 inasmuch as they "provide an

12 Not all judges at all times share this type of objection to constitutional theory. Compare, for example, the very different type of judicial critique of the academy made by Judge J. Skelly Wright more than forty years ago. J. Skelly Wright, Professor Bickel, the Scholarly Tradition, and the Supreme Court, 84 Harv. L. Rev. 769 (1971). Still, the kinds of criticisms advanced by Judges Posner and Wilkinson are not altogether uncommon ones today.

13 Richard A. Posner, Reflections on Judging 167 (2013).

$14 I d$.

15 Id. at 166.

16 Id. at $149,178$. 
escape from the need to grapple with the complexity of today's world." 17 As an alternative, Posner advocates "[a] realistic approach to interpretation ... that is analytically simple, that shifts the judicial focus to factual inquiry." 18 This approach has three features:

[If] the statute is clear, fine; if it's not clear, let's try to figure out what the legislature's general aim or thinking was and interpret the statute to advance that aim. .. . If we can't figure out what the aim is, we'll have no alternative but to assume the role of pro tem legislators and impose some reasonable meaning on the statute. ${ }^{19}$

Beyond this, there is little, if anything, that constitutional theory can contribute: "Theories of statutory and constitutional interpretation are clutter and the last thing our courts need is more clutter."20

The ideas in Reflections on Judging are the latest developments of arguments that Judge Posner has elaborated for decades. In 1990, Posner published The Problems of Jurisprudence, ${ }^{21}$ where he turned from his earlier focus on law and economics and law and literature more explicitly toward constitutional theory and constitutional interpretation. In chapter ten-"How to Decide Statutory and Constitutional Cases"-Posner raises certain core ideas about constitutional interpretation which recur in his later thought and which form the foundation of his judicial pragmatism:

Interpretation can be decoding of communications (and there it is least problematic), understanding, translation, extension, completion, transformation, even inversion. All that the term means concretely is that there is a text in the picture, the text is authoritative, and the decision must be related in some way to the text. Although this formulation may be slightly more directive than a definition of interpretation as the mediation of reality by language, it is not a formula for distinguishing sound interpretations from unsound ones. Maybe there is no formula, no methodology. Correctness in interpretation depends on the goal of the particular kind of interpretation .... But there is no agreement on what the goal of statutory or constitutional interpretation is. Maybe there are plural goals-fidelity to framers' intent, certainty, coherence, pragmatically good results. These are related, but different interpreters will give them different weights. ${ }^{22}$

Several important ideas emerge in this discussion. First, interpretation is not a single activity or enterprise with a uniform meaning. Stripped of its connection to the specific functions and purposes of the interpreter, the essence or kernel of interpretation consists only in the existence of a text and some connection between that text and a particular judgment. Very little of interest, therefore, can be said about interpretation in the abstract or in isolation; indeed, in that vacuum, interpretation might just as easily signify

$17 I d$. at 149.

$18 I d$. at 234.

19 Id. at $234-35$.

$20 I d$. at 234.

21 Richard A. Posner, The Problems of Jurisprudence (1990).

22 Id. at 299. 
"understanding" the meaning of a text as an "inversion" of that understanding. "Interpretation butters no parsnips." 23

Second, the passage illustrates a kind of perspectivalism. Interpretation takes shape only by its association with an interpreter and the aims or goals of that interpreter. It is the role of the interpreter-his particular functions, duties, purposes, and perspectives-that shapes his interpretive goals and gives the activity of interpretation its meaning. Likewise, the interpretation of a text depends on the role of the interpreter. Interpretive role and interpretive meaning are therefore intimately connected. "Law is an activity rather than a concept or a group of concepts," 24 and any activity is pursued by an actor through whose perspective the activity must be understood.

Third, it is impossible to judge whether an interpretation is sound or unsound without recourse to the role of the interpreter. This is in part because, as above, interpretation gains its particular meaning only as a practical activity pursued by an interpreter. But it is also because of the plurality of sound interpretive aims or goals, and the laudable desire of conscientious interpreters to pursue those goals simultaneously. There is no single goal of interpretation, and no single goal of constitutional interpretation. ${ }^{25}$ Reasonable goals of constitutional interpretation can and often do conflict. When they do, whether a sound interpretation demands the particular ranking of values that is selected will again depend on the interpreter's role and the perceived hierarchy of interpretive aims as influenced by that role.

Judge Posner connects these ideas to an early account of judicial pragmatism and applies them to Brown v. Board of Education, which Posner claims "cannot be shown to be correct as a matter of interpretation." 26 What he means is that the authority of text-if considered alone-cannot justify the decision in Brown. Indeed, it was the "vagueness of the text that permitted reexamination of [Plessy $v$. Ferguson] in light of half a century of social and political change." 27 He insists, however, that the "possible dispositions toward Brown" are not exhausted by "interpretive certainty [or] utter agnosticism."28 Instead, "our legal certitudes are pragmatically rather than analytically grounded," 29 and the pragmatic toolkit includes "political history, common sense and common knowledge, and ethical insight." 30 Posner is also plain that these grounds are well within the ken of the judicial role. ${ }^{31}$ And it is the "pragmatist tradition" which is largely responsible for the

\footnotetext{
$23 I d$. at 460.

24 Id. at 459.

25 This is in part because of the nature of interpretation, but also because of the openended quality of the portions of the text of the U.S. Constitution. See id. at 141.

$26 \quad I d$. at 302.

27 Id. at 307.

$28 I d$. at 308.

$29 I d$.

$30 \quad I d$. at 309 .

$31 \quad I d$. at 308.
} 
healthy attack on "foundations, on certitudes, on tradition, [and] on Grand Theories."32

Many of these ideas reappear and are sharpened in Overcoming Law. The four chapters comprising the second part of Overcoming Law discuss constitutional theory, the most interesting of which is chapter four- "Top-Down and Bottom-Up Reasoning." There Judge Posner describes "top-down" constitutional theories as those where

the judge or other legal analyst invents or adopts a theory about an area of law-perhaps about all law-and uses it to organize, criticize, accept or reject, explain or explain away, distinguish or amplify the decided cases to make them conform to the theory and generate an outcome in each new case as it arises so that it will be consistent with the theory. ${ }^{33}$

Though he acknowledges his own academic contribution to certain top-down theories, ${ }^{34}$ he does not believe that most of them are relevant to constitutional adjudication. Posner criticizes Ronald Dworkin's classic top-down theory of the Constitution at length, arguing that Dworkin would do better simply to acknowledge that his theory of, for example, the right to abortion has nothing to do with the text of the Constitution but is purely an exercise in liberal political theory. ${ }^{35}$ The fundamental problem is lack of candor about one's interpretive role and aims: Dworkin is a political philosopher, and his interpretive purposes and perspective are those of the liberal egalitarian theorist. Those purposes predetermine "his general theory of constitutional law, in which the clauses merge and lose their distinctness and the issue of the right of abortion becomes the place of such a right in the liberal theory of the state." 36

Judge Posner's point is similar to the one in Problems: the plausibility of an interpretation depends on the role of the interpreter and his particular function, aims, and perspective. And any interpretation cannot be described as sound or unsound outside the context of that role. The durability and appeal of top-down theories has far more to do with the attractions of "temperament, emotion, or personal experience" 37 than it does with their convincing resistance to countervailing arguments. Posner concludes his criticism of top-down theories with puzzlement over the assertion that they are derivable as an "analytical" matter, and that contrary interpretations of, for example, the religion clauses or the Due Process Clause are simply founded on "mistake[s]" or confusions. ${ }^{38}$ The soundness of a constitutional

$32 \quad I d$. at 462.

33 Posner, supra note 8, at 172.

34 Id. at $172-73$.

35 Id. at $175-88$.

36 Id. at $185-86$.

37 Id. at 186.

38 Id. at 187-88; see also id. at 466-67 ("The razor-sharp logical and polemical skills that we associate with Anglo-American philosophy are great tools of criticism but do not get one very far toward the solution of practical legal problems, such as what to do about abortion or coerced confessions or capital punishment."). Posner's most extensive critique 
interpretation, Posner writes, does not depend on its capacity to prove by argument that competitor interpretations are just confused or based on incorrect analysis. ${ }^{39}$

These themes recur in some of Judge Posner's later books, and it is in these that Posner's judicial pragmatism is more fully developed as a reaction against both philosophical and legalistic views. In Law, Pragmatism, and Democracy, for example, Posner explains the distinction between "philosophical pragmatism" and "everyday pragmatism," arguing that the latter is the sort which applies to adjudication. "If you are an everyday pragmatist," he writes,

[Y] our pragmatism is likely to spill over into your practice as a judge or practicing lawyer. Certain characteristics of American society . . . discourage reflection and abstract thought, neither of which has a commercial payoff, and encourage the bracketing of deep issues because they tend to disrupt and even poison commercial relations among strangers. An everyday pragmatist in law, an everyday-pragmatist judge for example, wants to know what is at stake in a practical sense in deciding a case one way or another .... The pragmatic judge does not deny the standard rule-of-law virtues of generality, predictability, and impartiality, which generally favor a stand-pat approach to novel legal disputes. He just refuses to reify or sacralize those virtues . . . . He is impatient with abstractions like "justice" and "fairness," with slogans like "self-government" and "democracy," and with the highfalutin rhetoric of absolutes-unless he is persuaded that such flag-waving has practical social value. For the everyday pragmatist . . moral, political, and legal theories have value only as rhetoric, not as philosophy. ${ }^{40}$

Posner's emphasis on the "commercial" or "business-like" character of judicial pragmatism conjoins his views of adjudication to his other academic work on law and economics. And Posner's judge-pragmatist exemplar is Justice Oliver Wendell Holmes, ${ }^{41}$ about whom he has written often and admir-

of the application of moral and political philosophy to law is Richard A. Posner, The Problematics of Moral and Legal Theory (1999).

39 Soundness in constitutional interpretation depends instead on the function that the interpreter is carrying out:

$[\mathrm{N}]$ one of the weapons in the armory of the analytic philosopher or expert legal reasoner will or should deflect a person who believes that the fetus is a human being and the abortionist a murderer. Those beliefs, like other fundamental beliefs, live below reason and are not the less worthy for doing so.

Posner, supra note 8, at 188 (citing Hyman Rodman et al., The Abortion Question (1987)).

40 Richard A. Posner, Law, Pragmatism, and Democracy 11-12 (2003) [hereinafter Posner, LAw]; see also id. at 49-50 ("I have found little in . . modern pragmatic philosophy that law can use. But the pragmatic mood . . . has much to contribute to law."); Richard A. Posner, The Rise and Fall of Judicial Self-Restraint, 100 CALIF. L. Rev. 519, 539 (2012) ("Judges who don't insist that a legalistic algorithm will decide every case are what I call 'pragmatists,' not in some pretentious philosophical sense but in the sense of an approach to decision making that emphasizes consequences over doctrine.").

41 Holmes combines ideal features of philosophical and everyday pragmatism in Posner's account. See Posner, Law, supra note 40, at 57-59; see also PosNer, supra note 8, at 
ingly. ${ }^{42}$ The "lesson suggested" by Holmes's career is that the ideal legal thinker "should be cultivated, broadly educated, and intellectually wellrounded (rather than merely proficient in the doctrinal analytics taught by Langdell and his successors) - not that any of the keys to understanding law [are] held by disciplines other than law." ${ }^{3}$ Yet Posner is confident that the perspective that most American judges-even those many that do not attain to the Holmesian ideal-bring to their work, including their work of constitutional interpretation, is that of everyday judicial pragmatism. ${ }^{44}$ Therefore their constitutional opinions can only be understood as interpretive acts, and judged as sound or unsound interpretations, through the prism of judicial pragmatism rather than academic constitutional theory.

Yet if philosophical academic theory has little value for the everyday pragmatist judge, neither does the "bottom up," 45 rigorously legalistic approach to adjudication, which is forcefully attacked by Judge Posner in How Judges Think. "Legalism" is the view that "judicial decisions are determined by 'the law,' conceived as a body of preexisting rules found stated in canonical legal materials, such as constitutional and statutory texts and previous decisions of the same or a higher court, or derivable from those materials by logical operations." ${ }^{46}$ It is a fundamentally misguided method of constitutional interpretation that ignores the value of "looseness"- "flexible, or nonliteral" judicial construction that is capable of making sense of constitutional provisions "ratified more than two centuries ago." ${ }^{7}$ Though Posner admits

195-96 ("If Holmes had the finest philosophical mind in the history of judging, one might think him the prime candidate to have worked out the sort of comprehensive, top-down theory that Dworkin wants to bring to bear on questions of constitutional interpretation. But Holmes's philosophical bent . . . was manifested in [his] bringing to bear on discrete constitutional issues the curious mélange of pragmatism, Social Darwinism, logical positivism, existentialism, vitalism, and other 'isms' that is his rich but far from univocal philosophical legacy.”).

42 See, e.g., Oliver Wendell Holmes, Jr., The Essential Holmes: Selections from the Letters, Speeches, Judicial Opinions, and Other Writings of Oliver Wendell Holmes, Jr. (Richard A. Posner ed., 1992).

43 Richard A. Posner, The Decline of Law as an Autonomous Discipline: 1962-1987, 100 Harv. L. Rev. 761, 763 (1987) (including Benjamin Cardozo, Louis Brandeis, Roscoe Pound, John Wigmore, Felix Frankfurter, Karl Llewellyn, Learned Hand, Jerome Frank, Henry Hart, and Lon Fuller in this description).

44 See Holmes, supra note 42, at 57.

45 Posner, supra note 8, at 176-77.

46 Posner, supra note 7, at 41 (citing Frederick Schauer, Formalism, 97 YAle L.J. 509 (1988)); see also Posner, supra note 40, at 520 (describing "legalism" as the view that "judges apply law, they don't make it").

47 Richard A. Posner, In Defense of Looseness: The Supreme Court and Gun Control, New Republic, Aug. 27, 2008, at 32, 32-35, available at http://www.newrepublic.com/article/ books/defense-looseness; see also Posner, supra note 40, at 539 ("And loose construction, when applied to a provision of the Constitution, is not a theory, but rather a license to read into the provision a judge's views of sound policy responsive to modern problems. It is when judges have such a license that there is pressure for a doctrine of judicial selfrestraint."). 
that there is a "solid legalist core in judicial decision making even at the highest levels," he criticizes even "moderate legalists" for their marginalization of the role of political ideology and discretion in adjudication. ${ }^{48}$ While a judicial pragmatist is sensitive to the "systemic" effects of a decision, those effects are given unwarranted weight by legalists. ${ }^{49}$ And judicial pragmatism does its real work-it is "what judges . . . do"-where "orthodox legal materials do not provide a secure bridge to decision and the judge lacks an overarching theory to plug the gap." 50 It is unsurprising to Posner that legalism's failure-and pragmatism's necessity-is most acutely felt in constitutional interpretation. ${ }^{51}$

The relationship of legalism and judicial restraint is complex, but Judge Posner (unlike Judge Wilkinson) sees them in tension: the more inclined a judge is to defer to other departments of government in constitutional matters, the less susceptible he will be to claims that judges are formalists and to the shibboleth that they simply "apply law, they don't make it." 52 Yet judicial restraint — whose adherents, Posner notes, include Wilkinson ${ }^{53}$ —is not a sustainable approach to constitutional adjudication. It has died in both the academy and in the courts-in the former due to its "incoherence" and to the rise of constitutional theory; in the latter due to the "exuberant activism" of the Warren Court beginning with Brown, an eminently unrestrained decision whose correctness no one today would deny. ${ }^{54}$ The most that may be said for judicial restraint in Posner's account is that it, like legalism, may at times be a pragmatic technique or strategy. ${ }^{55}$ But restraint alone-if not integrated as one set of considerations within a larger pragmatic approachis inadequate. ${ }^{56}$

\section{B. Wilkinson's Judicial Restraintism at Rest}

The signature phrase for Judge Wilkinson's approach to constitutional adjudication is "judicial restraint." But Wilkinson's particular version of judicial restraint is not across-the-board restraint of the sort associated with Justice Oliver Wendell Holmes. Instead, Wilkinson favors a version qualified by certain substantive commitments (such as to national unity and against racial

\footnotetext{
48 Posner, supra note 7 , at 49 .

49 Posner, supra note 40, at 541.

$50 \quad I d$. at 542.

51 See id. at 542-43.

52 Posner, supra note 40, at 520-21, 536.

53 Id. at 534-35.

$54 \quad I d$. at 546.

55 See Posner, supra note 7, at 287-88 ("Judicial modesty or self-restraint . . . is not a legalist idea but a pragmatic one."); $i d$. at 80-81 (describing strategic reasons for legalism and stating that "it will sometimes be difficult to distinguish a pragmatist judge from a legalist one").

56 Posner, supra note 40, at 554 ("I would . . . suggest simply that the considerations I have listed in favor of restraint are considerations that a sensible, pragmatic judge should take account of, along with the other considerations that bear on decisions in tough cases.").
} 
grouping) and designed to serve certain ends (such as civility and decreased polarization). And while he resists the label of "theory" to describe the set of commitments that guide him in constitutional adjudication, ${ }^{57}$ Wilkinson nevertheless advocates that judges decide constitutional cases by reference to a particular school of thought about constitutional adjudication.

That is the school of "restraintist thought" whose primary judicial exemplars for Judge Wilkinson are the second Justice John Marshall Harlan, Justice Felix Frankfurter, and Justice Lewis Powell. ${ }^{58}$ Judges in this school reject as a "mirage" the "idea of literal answers leaving no room for judicial insight."59 As with Posner's praise of "looseness," Wilkinson's rejection of neat and readily applied solutions is a recurring theme in his critique of constitutional theory.

The challenge for the judge in this school-a school that accepts "a role for reason within the rule of law" - is to distinguish the "voice of legal reason" from "idiosyncratic preference." 60 That Judge Wilkinson believes there is something called "legal reason" marks a contrast with Judge Posner, who has argued that "no general analytic procedure distinguishes legal reasoning from other practical reasoning." 61 Wilkinson also describes "legal reason""the process of applying impersonal principles of law to varying facts" 62 -in precisely the way that Posner criticizes as legalist. ${ }^{63}$ It is thus unsurprising that Posner describes the article in which Wilkinson lays out his "restraintist thought" as a "legalist manifesto." 64

Yet in explaining how to distinguish the "voice of legal reason" from "idiosyncratic preference," 65 Judge Wilkinson does not sound like the kind of legalist that Judge Posner criticizes for overemphasizing the determinacy of conventional legal materials. Wilkinson turns not to the language of legal determinacy but rather to the language of virtue and vice. He commends the virtue of intellectual humility, which will help the judge "avoid confounding the familiar with the necessary and the unwise with the unconstitutional."66 And he counsels judges not to succumb to the judicial "temptation to formulate wise policy" in undertaking the judicial "duty to make great choices." 67

57 See Wilkinson, supra note 4, at 116 ("I have no theory. I offer only a set of worn and ordinary observations that have all been voiced many times before.").

58 J. Harvie Wilkinson, III, The Role of Reason in the Rule of Law, 56 U. CHI. L. REv. 779, 802-03 (1989).

59 Id. at 803.

$60 I d$.

61 Posner, supra note 7, at 248.

62 Wilkinson, supra note 58, at 792.

63 Posner, supra note 7, at 41 ("Legalism, considered as a positive theory of judicial behavior (it is more commonly a normative theory), hypothesizes that judicial decisions are determined by 'the law,' conceived of as a body of preexisting rules found stated in canonical legal materials.”).

64 Id. at 262.

65 Wilkinson, supra note 58, at 803.

$66 I d$. at 803 (footnote omitted) (internal quotation marks omitted).

67 Id. at 804 . 
The commitments of the Harlan/Frankfurter/Powell restraintist school ground Judge Wilkinson's criticisms of both originalism and what might be called constitutional moralism. Writing in the late 1980s, Wilkinson grouped Judge Robert Bork's originalism and Justice Hugo Black's literalism into the same "school" and lauded their insistence upon "standards extrinsic to the judges themselves." 68 This emphasis on extrinsic standards may sound like the legalism that Judge Posner contrasts with pragmatism. But Wilkinson is not a thoroughgoing legalist. For he criticized Bork's and Black's assumption that "external standards will always yield answers" and their "suggestion that intentionalism or originalism leaves little for the judge to do but look." 69 Nevertheless, Wilkinson does believe that the legalistic concept of extrinsic standards is a vital component of wise adjudication. In the same article, Wilkinson also criticized academic theory's importation of abstract moral reasoning into constitutional adjudication. Judicial invocation of the "cosmic constitutional values" of "equality, liberty, property, [and] due process" claims too "spacious a mandate for judicial interpretation."70 Constitutional moralism of this sort tends to confirm "the fear[ ] . . that judicial reason has no foundation in objectivity or restraint."71

The same concerns animate Judge Wilkinson's recent book, Cosmic Constitutional Theory, which explores "the surprising inability of modern constitutional theories of all stripes to restrain courts from imposing on others their personal vision of the proper good."72 Wilkinson takes on not only originalism and living constitutionalism, but also political process theory and pragmatism. Although he does not put it this way, all of these "cosmic" theories are vulnerable to objections that they proceed from the top-down and they insist on methodological purity that marginalizes legitimate judicial discretion.

In criticizing pragmatism as a cosmic constitutional theory, Judge Wilkinson acknowledges that Judge Posner disavows the label of "theory" for his pragmatic approach to constitutional adjudication. But Posner's "supposedly antitheoretical pragmatism turns out to be just like the other cosmic constitutional theories."73 Pragmatism (like living constitutionalism) mistakenly "ascribes to judges a role that is beyond their democratic authority by transplanting the methodology and vision of common law adjudication into the inhospitable soil of modern constitutional law."74 And pragmatism (like originalism) problematically "places in the hands of judges a methodology at once deceptively objective and impossible to deploy."75

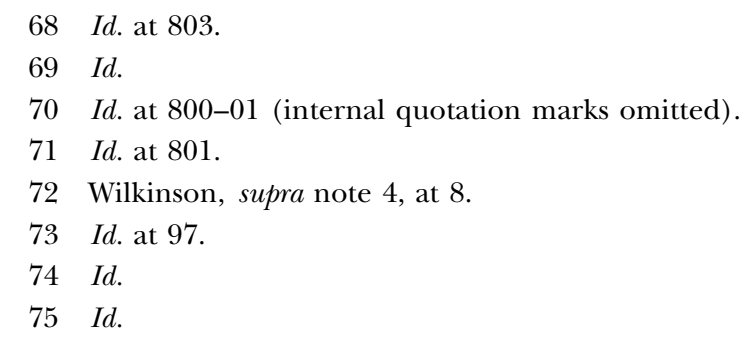


In developing his criticisms of Posnerian pragmatism, Judge Wilkinson appeals repeatedly to conceptions of judicial role, and specifically to "the values of traditional adjudication." 76 Wilkinson contrasts fidelity to past decisions (characteristic of the judge) with care for future consequences (characteristic of the legislator). He sometimes criticizes the pragmatic judge as a passive victim of mistaken role: neglect of the values of traditional adjudication leaves the judge "adrift in a sea of legislative discretion." 77 At other times, however, Wilkinson chastises the pragmatic judge as an activist policymaker: "pragmatism's methodology provides generous incentives, excuses, and cover for judges to turn away from their duty of restraint and toward the role of aggressive junior varsity legislator."78

Judge Wilkinson worries that Judge Posner's instrumentalist understanding of judicial role simply cannot secure the restraint that Wilkinson believes is required by a proper understanding of the judicial role: "pragmatic judges may start by asking themselves what result would be practically preferable and only then ask whether the traditional materials block that result."79 Whereas pragmatic judges look to the past only instrumentally, traditional judges seek to play by pre-existing rules because they are judges who "deeply believe they should." 80

Notwithstanding these criticisms of judicial pragmatism, Judge Wilkinson does not embrace thoroughgoing legalism. In a retrospective evaluation, Wilkinson charged that "the Rehnquist Court became progressively unable to distinguish between those occasions that legitimately called for the exercise of judicial wisdom and those that called for the application of law." 81 In his view, "[s] ome contexts do indeed call for wise decisionmaking." 82 Judicial wisdom is necessary, according to Wilkinson, in circumstances when constitutional text clearly protects some right, but the precise contours of that protection are not clearly specified. ${ }^{83}$ By way of illustration, "the Constitution makes a strong textual commitment to free religious exercise and forbids, at a minimum, the establishment by government of any church or faith." 84 But the text of the First Amendment "provides sparse guidance on how close cases such as McCreary and Van Orden [which dealt with different public displays of the Ten Commandments] should be decided." 85 Agreeing with Justice Breyer's characterization of these cases as "borderline" and "fact-

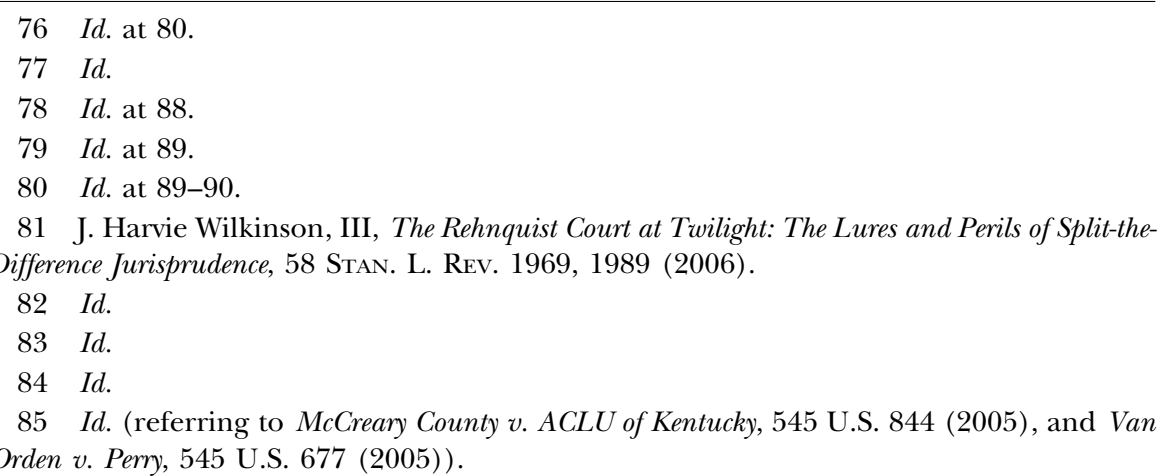


intensive," ${ }^{86}$ Wilkinson concluded that "the occasion called fairly for judicial wisdom, because the Constitution authorized judicial involvement but provided no neat answers." 87

Judge Wilkinson's extrajudicial analysis of two other recent Supreme Court cases, District of Columbia v. Heller ${ }^{88}$ and Parents Involved in Community Schools v. Seattle School District No. $1{ }^{89}$ adds further detail to his approach. Wilkinson's analysis of Heller develops his conception of judicial restraint, while his discussion of Parents Involved illustrates the limits he would impose on restraint-based reasoning.

Heller was a five-to-four decision recognizing a constitutional right to gun possession for self-defense in one's home. ${ }^{90}$ The decision occasioned a blistering article from Judge Wilkinson, who charged the Supreme Court with committing the same sins as in Roe $v$. Wade. ${ }^{91}$ Although he believed that Heller was not as egregious as Roe, "the methodological similarities . . . are large." 92 In particular, "[b] oth cases interpreted ambiguous constitutional provisions and both claimed to find in them mandates that put to rest an extremely controversial issue of social policy, in the process overturning decisions by popularly elected officials." 93 Wilkinson characterizes as "equivocal" the historical and textual arguments that consumed most of Justice Scalia's opinion for the Court and Justice Stevens's dissenting opinion. ${ }^{94} \mathrm{He}$ argues that the Court needed to make a discretionary decision, and he offers judicial self-restraint as a tiebreaker: "[w] hen a constitutional question is so close, when conventional interpretive methods do not begin to resolve the issue decisively, the tie for many reasons should go to the side of deference to democratic processes." 95

Yet there was little role for judicial restraint as a tiebreaker in Judge Wilkinson's appraisal of Parents Involved. The Supreme Court held unconstitutional two school districts' student-assignment plans because of the way that those plans included race-based decisionmaking. ${ }^{96}$ Adopting an unabashedly anti-restraint stance, Wilkinson praised Chief Justice Roberts's plurality opinion for its breadth, and in particular for its statement that " [ $\mathrm{t}]$ he way to stop discrimination on the basis of race is to stop discriminat-

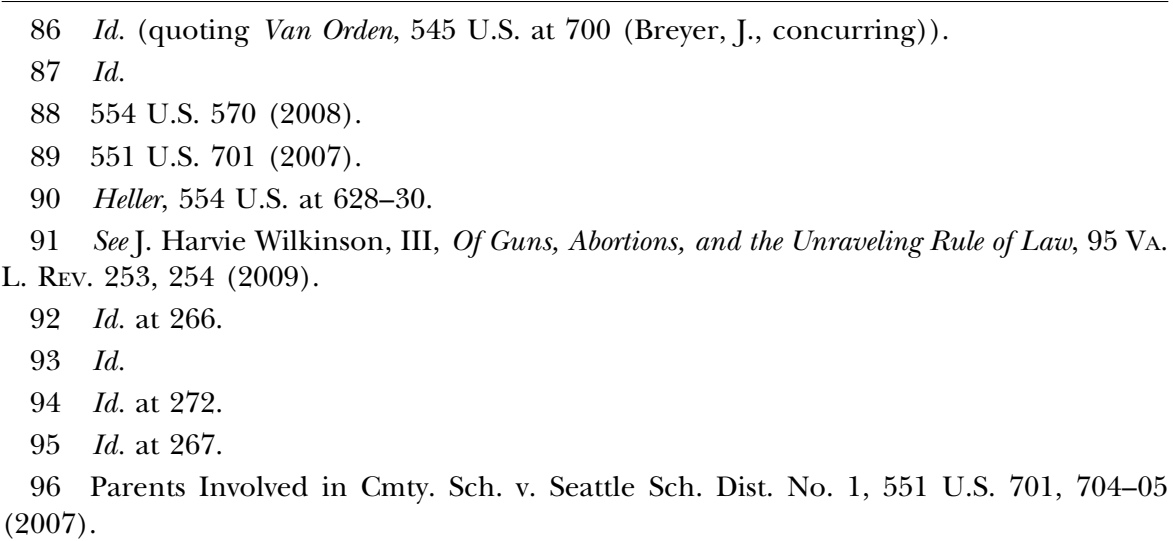


ing on the basis of race." "97 Wilkinson acknowledges "great risks in this sort of ringing clarity, particularly in an area so burdened by history, so fraught with contemporary controversy, and so open to strong opposing argument."98 But he believes that "there are far greater risks in failing to defend a principle that is not easily sliced and diced or otherwise compromised."99 Accordingly, he criticizes Justice Kennedy's concurrence for failing to recognize the substantial "drawbacks of allowing just a little use of race" ${ }^{100}$ : extensive litigation, the difficulty of drawing lines, and the risk that "citizens may start perceiving themselves in the officially sanctioned categories."101

Judicial restraint, "admirable as a general matter, carries three distinct risks when racial classifications are involved": risks to the rule of law ("breaking the Fourteenth Amendment's most solemn command"), risks to the individual citizen ("whose rights are determined by resort to his race"), and risks to society itself ("of interminable race-based rancor") ${ }^{102}$ Justice Breyer's dissent appeals to all the values that Judge Wilkinson himself champions: "deference to democracy," "appreciation for local experimentation," "diminished litigation," "judicial restraint," and "above all, the binding ties to one nation that conservatives have wanted all along."103 Yet the opinion "fail[s] ultimately to persuade," Wilkinson asserts, "because it recognizes few, if any, limits to the explicit use of race and ethnicity in public decisions."104

Judge Wilkinson's praise of Chief Justice Roberts's opinion in Parents Involved for its unstinting adherence to a particular vision of racial equality may seem surprising in light of the critical project of Cosmic Constitutional Theory. But the Parents Involved analysis reflects a strand of Wilkinson's extrajudicial writing not discussed in that book. That strand is on open display, however, in his Madison Lecture delivered at N.Y.U. Law School, Toward One America: A Vision in Law. ${ }^{105}$ In that lecture, Wilkinson argued-against the "partisan and polarizing" spirit of the age ${ }^{106}$ _that "law should consciously aspire to promote a stronger sense of national cohesion and unity." 107 This aspiration to maintain "a concept of American nationhood in a divisive and rapidly evolving age," Wilkinson asserted, should become a "third great purpose" of law, together with "the preservation of order in which freedom may flourish and the protection of liberty itself from overreaching by the

97 J. Harvie Wilkinson, III, The Seattle and Louisville School Cases: There Is No Other Way, 121 Harv. L. Rev. 158, 161 (2007) (quoting Parents Involved, 551 U.S. at 748 (opinion of Roberts, C.J.)).

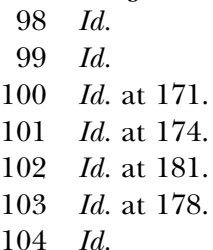

105 J. Harvie Wilkinson, III, Toward One America: A Vision in Law, 83 N.Y.U. L. Rev. 323 (2008).

$106 \quad I d$. at 323.

107 Id. at 324. 
State." 108 To advance these three broad purposes, Wilkinson exhorts lawyers and judges to follow seven principles: (1) respect judicial restraint; (2) be sparing in what we seek to constitutionalize; (3) value the nationalism in our Constitution; (4) restore a constitutional respect for community; (5) reduce polarization (but not necessarily partisanship); (6) do not premise public allocations and benefits on ethnicity and race; and (7) appreciate the importance of process. ${ }^{109}$

These principles are closely divided between those that counsel moving slowly and carefully and those that point in particular directions to move. But together they add up to the kind of normative theory that Judge Posner criticized in his Madison Lecture at the same law school a decade earlierAgainst Constitutional Theory. ${ }^{110}$ Posner easily could level against Wilkinson's antitheoretical restraintism the same criticism that Wilkinson levels against Posner's antitheoretical pragmatism: in the end it appears to be just another constitutional theory. For while Wilkinson's vision for law is marked by skepticism toward theorizing of a certain sort, it is also animated by his commitment to a third "great purpose" of law to be implemented through a set of normative propositions.

\section{Posner and Wilkinson at War?}

The foregoing discussion of Judge Posner's and Judge Wilkinson's extrajudicial writings on constitutional theory recasts what are often claimed to be their fundamentally contrasting approaches in an entirely different lightfor they share a very similar critical perspective. Indeed, while differences between the two remain, we believe that their practical significance has been misunderstood and greatly overstated.

Consider their respective prescriptions for adjudication when conventional legal materials "run out." Judge Posner says that discretion fills the gap; ${ }^{111}$ Judge Wilkinson calls that discretion "wisdom."112 This terminological difference may appear to be more than semantic, but it is not. The discretion to which Posner refers is judicial discretion, and it is constrained by judicial role. The same is true for Wilkinson's wisdom. In their extrajudicial writing, both Posner and Wilkinson regularly raise the constraints of judicial role in the practice of constitutional adjudication. As Posner explains, "judges in our system operate under both internal and external constraints. That is as true of pragmatic judges as it is of legalist judges." 113 As judges, the pragmatic judge may be no less restrained than the legalist judge; the legalist no more restrained than the pragmatic.

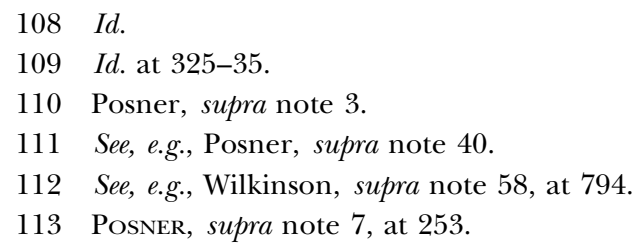


The fact that Judge Posner and Judge Wilkinson are judges explains another common feature of their extrajudicial writing. Both regularly situate their approaches to adjudication (constitutional and otherwise) by reference to other judges. Posner proclaims that " $[\mathrm{m}]$ any of the most highly regarded judges and Justices in American legal history have . . . been pragmatists." 114 And he recommends greater attention to the "neglected literature" on "writing by judges on judging." 115 Wilkinson associates himself with a particular "school" of restraintist thought, identifying the school's judicial exemplars by name. ${ }^{116}$ And in assessing their judicial handiwork, Wilkinson singles out individual judges for praise or blame, linking his case-specific assessments to broader evaluations of each judge's oeuvre. ${ }^{117}$

The perception that Judge Posner and Judge Wilkinson differ significantly may be more a function of their professions in extrajudicial writing than of practically meaningful differences in how they undertake their professional obligations. It may be that their extrajudicial accounts of one another overlook important similarities stemming from their common judicial role. The next Part explores their judicial writing in constitutional cases where their at-rest commitments to pragmatism or restraintism are most likely to be apparent.

\section{The Judge at Work: Judicial Writing}

The previous Part explored the critique of constitutional theory advanced in the extrajudicial writing of Judges Posner and Wilkinson. This Part examines the constructive dimension of their thought in the artifacts of judicial decisionmaking-cases. It explores how that constructive dimension is manifested and developed in a selection of constitutional decisions authored by these same judges.

This examination exposes a fact that is universally missed by critics of the judges' thought: more than a theory of constitutional interpretation (such as pragmatism or restraintism), what these judges bring to the work of constitu-

114 Posner, supra note 40, at 542. Posner adds that " $[\mathrm{t}]$ his point is overlooked in Judge Wilkinson's article, [Of Guns, Abortion, and the Unraveling Rule of Law, supra note 91]. He regards legal pragmatism as an activist theory, while describing famous pragmatists like Holmes as apostles of restraint." Id. at 542 n.82.

115 Posner, supra note 7, at 256; see id. at 257-59, nn. 40-54 (citing, inter alia, Frank M. Coffin, On Appeal: Courts, Lawyering, and Judging (1994); Henry J. Friendly, Benchmarks (1967); Holmes, supra note 42; Michael Boudin, Madison Lecture, Judge Henry Friendly and the Mirror of Constitutional Law, 82 N.Y.U. L. REv. 975 (2007); Charles E. Clark \& David M. Trubek, The Creative Role of the Judge: Restraint and Freedom in the Common Law Tradition, 71 Yale L.J. 255 (1961); Walter V. Schaefer, Precedent and Policy, 34 U. Chi. L. Rev. 3 (1966); Harlan F. Stone, The Common Law in the United States, 50 Harv. L. Rev. 4 (1936); Patricia M. Wald, Some Real-Life Observations About Judging, 26 IND. L. REv. 173 (1992)).

116 See, e.g., Wilkinson, supra note 58, at 802 (discussing Justices Black and Harlan and Judge Bork as restraintists).

117 See, e.g., Wilkinson, supra note 97 (discussing the work of, among others, Chief Justice Roberts and Justices Kennedy, Stevens, Breyer, Warren, and Burger). 
tional adjudication is a distinctive perspective that arises out of their particular role within the judicial hierarchy. Our study shows how role-based and institutional considerations shape and constrain these judges' implementation of their more general theoretical commitments in constitutional adjudication. Constitutional theory can and does affect the shape of their constitutional adjudication, but its influence is always less powerful than the influence of factors related to judicial office or role. And to the extent that constitutional theory does affect constitutional adjudication, it never does so detached or abstracted from the overarching institutional, dispositional, and role-based constraints that govern the judicial office.

We illustrate these points by considering selected constitutional cases authored by Judges Wilkinson and Posner while "at work." We have chosen pairs of cases involving three specific issues-gun possession for self-defense outside the home, partial-birth abortion, and perceived official favoritism of Christianity-because they involve hotly contested and controversial areas of constitutional law in which one might expect that the judges' extrajudicial constitutional theories would figure especially prominently. The cases selected address sufficiently similar legal issues to provide useful comparisons, and together encompass a sufficiently broad set of constitutional questions to offer insights about their approach to constitutional adjudication "at work."118

\section{A. Gun Possession for Self-Defense Outside the Home}

The first two cases in which we examine Judge Wilkinson and Judge Posner "at work" present the same question: does the right to possess a gun for self-defense-as recognized by the Supreme Court in District of Columbia $v$. Heller $^{19}$ and McDonald v. Chicago ${ }^{120}$-extend outside the home? Wilkinson and Posner have answered this question in different ways. In rejecting a constitutional challenge to a gun regulation, Wilkinson assumed that the right extends outside the home, but explicitly declined to decide that issue. ${ }^{121}$ Posner, by contrast, held a state law unconstitutional after concluding that it unjustifiably burdened the right to possess a gun for self-defense outside the home. ${ }^{122}$

118 Ordinarily, one might be uncertain how much of a judge's opinion-writing could be attributed to the judge's own pen because much opinion writing today is done by law clerks. But in the case of both Posner and Wilkinson, one can be fairly confident that the judges' opinion writing is substantially their own. Posner has indicated that he is the primary author of nearly all of his opinions. Richard A. Posner, How I Write, 4 ScRibes J. Legal Writing 45, 45-46 (1993). Although Wilkinson has not written publicly about his drafting process, his opinions have a distinctive and consistent voice (whereas the opinions of other judges whose clerks play a larger role vary significantly in style from year to year).

119554 U.S. 570 (2008).

120561 U.S. 742 (2010).

121 United States v. Masciandaro, 638 F.3d 458, 474 (4th Cir. 2011).

122 Moore v. Madigan, 702 F.3d 933, 942 (7th Cir. 2012). 
Each judge's respective approach to answering this question is facially consistent with his "at rest" theoretical commitments to restraintism and pragmatism, respectively. But depending on the meanings assigned to restraint and pragmatism, Wilkinson's opinion can also (and should also) be understood as pragmatic while Posner's opinion can also (and should also) be understood as restrained. Indeed, when assessed as intermediate appellate judges vis-à-vis their hierarchical superiors rather than solely by reference to their bottom-line conclusions, Wilkinson was more pragmatic than Posner, while Posner was more restrained than Wilkinson. Moreover, the judges' choices about how to operate within the role-based norms of judging mattered more to their decisions than an across-the-board application of their constitutional theories. We emphasize that these observations are not meant as accusations of hypocrisy. The judges' extrajudicial constitutional theories do affect their opinions. But these cases show that role-based considerations are primary.

In United States $v$. Masciandaro, ${ }^{123}$ Sean Masciandaro had been arrested for possessing a loaded handgun while he slept in his car in the parking lot of a recreational area maintained by the National Park Service, in violation of a federal regulation. ${ }^{124}$ Masciandaro argued that the Second Amendment protected his right to possess the gun for self-defense. ${ }^{125}$ A three-judge panel of the Fourth Circuit rejected the claim unanimously, but split in reasoning. ${ }^{126}$ Judge Niemeyer wrote for the panel on every issue in the case but one, concluding that the Second Amendment protected a right to possess a gun for self-defense outside the home, that laws and regulations burdening that right are subject to intermediate scrutiny, and that the federal regulation at issue satisfied intermediate scrutiny. ${ }^{127}$ Writing for himself and Judge Duffy, Judge Wilkinson joined every part of Niemeyer's opinion except for his conclusion that the Second Amendment protected a right to possess a gun for self-defense outside the home. ${ }^{128}$ Wilkinson explicitly declined to decide that issue. Instead, Wilkinson assumed without deciding that such a right existed, and then held that Masciandaro's challenge to his conviction failed because he agreed with Niemeyer's application of intermediate scrutiny. ${ }^{129}$

Judge Wilkinson deployed one argument for judicial restraint in general, and one argument for judicial restraint with respect to gun rights in particular. His general argument is democracy-based: "[t]o the degree that we push the right beyond what the Supreme Court in Heller declared to be its origin," Wilkinson wrote, "we circumscribe the scope of popular governance, move the action into court, and encourage litigation in contexts we cannot

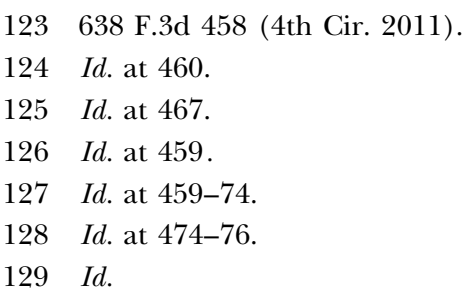


foresee." 130 This argument focuses on the relationship of the judiciary to the instruments of popular governance rather than the relationship of the inferior federal courts to their hierarchical superiors.

Judge Wilkinson's argument for judicial restraint with respect to gun rights in particular is consequentialist: " $[\mathrm{w}] \mathrm{e}$ do not wish to be even minutely responsible for some unspeakably tragic act of mayhem because in the peace of our judicial chambers we miscalculated as to Second Amendment rights." ${ }^{31}$ Standing alone, an unvarnished appeal to consequences seems like the kind of argument that Wilkinson "at rest" would abjure as nonjudicial. But Wilkinson "at work" tunes the argument from mayhem to a judicial key with an inference about Supreme Court intent: "[i]t is not far-fetched to think the Heller Court wished to leave open the possibility that such a danger would rise exponentially as one moved the right from the home to the public square."132

The second case involving the extension of Heller and McDonald outside the home is Moore v. Madigan. ${ }^{133}$ Judge Posner wrote for the majority on a split three-judge panel of the Seventh Circuit, holding that an Illinois law that amounted to an almost-complete ban of gun possession outside the home was unconstitutional. ${ }^{134}$

Judge Posner begins with a straightforward discussion of Heller and McDonald, stating that an "implication" of the historical analysis in those cases is that "the constitutional right of armed self-defense is broader than the right to have a gun in one's home."135 The opinion continues with the textual argument that "[a] right to bear arms . . . implies a right to carry a loaded gun outside the home." 136 Posner next turns to history, discussing such authorities as the 1328 Statute of Northampton, the 1686 King's Bench decision in Sir John Knight's Case, the 1707 third edition of Robert Gardiner's The Compleat Constable, and the fourth volume of Blackstone's Commentaries on the Law of England. ${ }^{137}$ Even as he interprets these authorities, Posner distances himself somewhat by making clear that his opinion's historical analysis is necessitated by Heller and McDonald: "[a]ll this is debatable of course, but we are bound by the Supreme Court's historical analysis because it was central to the Court's holding in Heller." 138

Having parsed Supreme Court statements, analyzed the text of the Second Amendment, and investigated English history, Judge Posner pivots to a discussion of twenty-first-century Illinois. He offers various hypothetical

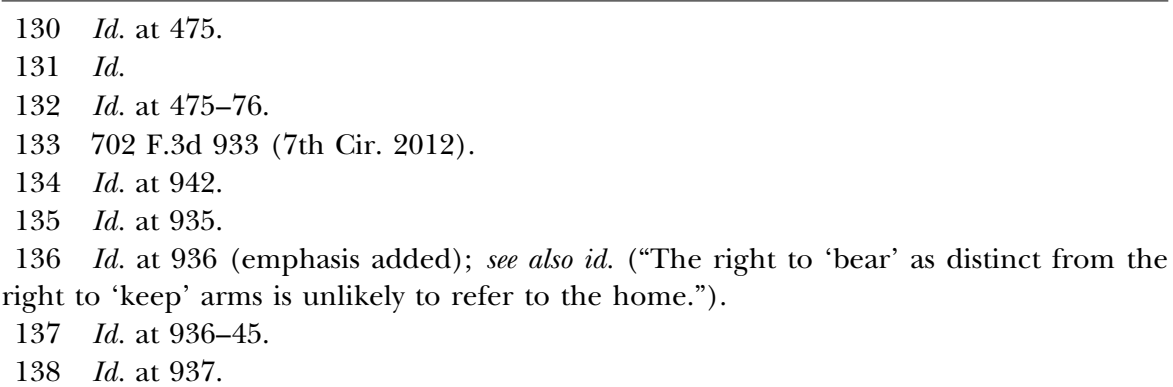


examples to show that any distinction between in-home and out-of-home gun possession "creates an arbitrary difference."139 The opinion continues with the sort of analysis from Posner-the-judge that one might expect from Posner-the-theorist. Relying on an array of social science sources, Posner concludes that "the net effect on crime rates in general and murder rates in particular of allowing the carriage of guns in public is uncertain both as a matter of theory and empirically" 140 and that "the empirical literature on the effects of allowing the carriage of guns in public fails to establish a pragmatic defense of the Illinois law." 141 He then ties this empirical excursion back to conventional legal analysis with a statement that simultaneously follows the Supreme Court's lead and undermines its approach:

Anyway the Supreme Court made clear in Heller that it wasn't going to make the right to bear arms depend on casualty counts. If the mere possibility that allowing guns to be carried in public would increase the crime or death rates sufficed to justify a ban, Heller would have been decided the other way, for that possibility was as great in the District of Columbia as it is in Illinois. ${ }^{142}$

In the balance of Judge Posner's opinion, he criticizes decisions by the Second and Fourth Circuits on similar Second Amendment challenges for failing to follow the Supreme Court's lead. The Second Circuit should have treated "the historical issues as settled by Heller," 143 while the Fourth Circuit should not have declined to pursue the Second Amendment's application beyond the home. Explicitly mentioning Judge Wilkinson-the only judge Posner singles out by name-Posner writes that the "vast terra incognita" that Wilkinson avoids "has been opened to judicial exploration by Heller and McDonald. There is no turning back by the lower federal courts."144

The opinion concludes with the same mixture of lower court passivity and pragmatism. Because Illinois failed to justify its "uniquely sweeping ban" by showing "an increase in public safety," Judge Posner writes, "[t]he Supreme Court's interpretation of the Second Amendment therefore com-

139 Id. Posner argues that it makes no sense for Illinois law to forbid a woman with a protective order against her violent husband from carrying a gun in public, while allowing "the resident of a fancy apartment building (complete with doorman) . . . to sleep with a loaded gun under her mattress." Id.; see also id. "To confine the right to be armed to the home is to divorce the Second Amendment from the right of self-defense described in Heller and McDonald.").

$140 I d$. As if to underscore his engagement with these social science sources, Posner at one point reproves plaintiffs' counsel in one of the appeals for presenting a modified quotation that resulted from deleting a particular clause without including ellipses. Id. at 938. $141 \quad I d$. at 939.

$142 I d$. (citation omitted).

143 Id. at 941. Posner also criticizes the Second Circuit for its reliance on Lawrence v. Texas, 539 U.S. 558 (2003), to single out the home for special protection: "[T] he interest in having sex inside one's home is much greater than the interest in having sex on the sidewalk in front of one's home. But the interest in self-protection is as great outside as inside the home." Moore, 702 F.3d at 941.

$144 I d$. at 942 (emphasis omitted) (internal quotation marks omitted). 
pels us to reverse . . . and remand . . . for the entry of declarations of unconstitutionality and permanent injunctions." ${ }^{45}$ A final pragmatic adjustment softens the immediate impact of the panel's compulsion by Supreme Court precedent. In recognition of the disruption that this ruling could have on the regulatory regime for guns in Illinois, the panel orders its mandate stayed for 180 days "to allow the Illinois legislature to craft a new gun law that will impose reasonable limitations, consistent with the public safety and the Second Amendment as interpreted in this opinion, on the carrying of guns in public."146

These opinions expose different features of "pragmatism" and "restraint" in the judges "at work" than they emphasize in their theorizing "at rest." With respect to the potential extension of Heller, Judge Wilkinson is more pragmatic while Judge Posner is more legalistic. Neither approach is more "judge-like" in the abstract, or even when assessed by their respective "at rest" views. Role-based considerations were more significant than their theories.

One common way to think about restraint is to ask how willing judges are to displace legislation enacted by electorally accountable actors. In this sense, Judge Wilkinson is more restrained than Judge Posner in these cases. This may be surprising inasmuch as Posner is thought to be a Holmesian, for Holmes was (in)famous for the extent to which he was willing to defer to legislation.

But there is another-less widely appreciated but still important-way to think about judicial restraint. That is to ask how closely a judge's approach to a case hews to that judge's substantive views about a particular area of law. In this sense, the judges' positions on the restraint spectrum flip. Both Posner and Wilkinson are strong critics of Heller and McDonald. Yet Posner extends the cases while Wilkinson confines them.

Judicial restraint is often thought of as involving a continuum of law as against ideology, where the relevant law is the substantive law. If that were the only type of law at issue, then one might conclude that Posner is more willing than Wilkinson to subordinate his views about the Second Amendment to the law, and that he is therefore more restrained than Wilkinson. But the relevant law is not only the applicable substantive law but also the law that structures the relationship between inferior federal courts and the Supreme Court. Highlighting this role-based, institutional feature of law exposes a neglected dimension of judicial restraint: passivity in transmitting the approach prescribed by the Supreme Court to new issues even if the resulting decision is unrestrained (or unpragmatic) along the dimension of substantive law.

This internal judicial notion of hierarchical restraint may explain another feature of Posner's Holmesianism. A Holmesian on an inferior federal court may view "legislation" by the Supreme Court (which is the way that

$145 I d$.

$146 I d$. 
Posner views constitutional decisions like Heller $)^{147}$ with the same moral and ideological indifference as legislation enacted by the legislature. If so, then passivity is the order of the day in both cases. These considerations of the judicial role therefore shed new light on the influence of constitutional theory on adjudication.

Even more than restraint, pragmatism may be understood in many ways. Yet one uniformly important feature of pragmatism is attention to consequences. Accordingly, one way to determine whether Judge Wilkinson or Judge Posner was more pragmatic in these cases is to ask which judge was more attentive to consequences. This assessment is tricky. While both judges were attentive to consequences, each manifested that attention differently. Both Wilkinson and Posner evaluated whether extending Heller and McDonald outside the home might cause increased violence. Posner examined the question by attending to social science literature and ultimately concluded that the evidence was equivocal. Wilkinson relied on speculation that was attentive to consequences when writing that " $[\mathrm{w}] \mathrm{e}$ do not wish to be even minutely responsible for some unspeakably tragic act of mayhem because in the peace of our judicial chambers we miscalculated as to Second Amendment rights." 148 Wilkinson's approach seems less pragmatic insofar as it turns on perceptions of consequences rather than hard data. But Wilkinson's particular justification for considering consequences is connected to a prediction about the limits of the Supreme Court's Second Amendment decisions and the need for deference by lower court judges to those predicted limits. The impact of pragmatism is thus conjoined to, and interlocked with, considerations of institutional role. Focusing on these role-based considerations again provides a usefully complicating perspective on the question of the influence of consequences on constitutional adjudication, and in so doing it improves our understanding of the influence of pragmatism.

\section{B. Partial-Birth Abortion}

Judge Posner and Judge Wilkinson have each issued two opinions addressing the constitutionality of legislative prohibitions of partial-birth abortion. Examining these opinions reveals not only that vertical stare decisis truly does constrain judges, but also that lower court judges use this rolebased constraint in different ways. For Posner and Wilkinson, pragmatism and restraint do not tug against the constraints of precedent in these opinions but rather color their use of precedent to advance pragmatic or restraintist judging more generally. These opinions point toward a distinct set of questions about constitutional adjudication from those generally studied by constitutional theorists. And the implication of these questions is that rather than focusing nearly exclusively on the Supreme Court and advocating an ideal type of interpretive or adjudicative theory, theorists ought also to

147 United States v. Masciandaro, 638 F.3d 458, 475 (4th Cir. 2011).

$148 I d$. 
examine constitutional interpretation and adjudication in light of judges' particular places and roles within an existing system of adjudication.

Judge Posner's two opinions on the constitutionality of a partial-birth abortion ban preceded both of Judge Wilkinson's. They also preceded, and in some ways previewed, the Supreme Court's decision in Stenberg v. Carhart that a state ban on partial-birth abortions was facially unconstitutional because it reached too broadly and did not contain a health exception. ${ }^{149}$

Judge Posner's first partial-birth abortion opinion was Planned Parenthood of Wisconsin v. Doyle, addressing a Wisconsin law imposing a criminal prohibition on partial-birth abortion. ${ }^{150}$ Much of Posner's reasoning in his panel opinion, holding Wisconsin's partial-birth abortion ban unconstitutional, consists of unexceptional (but nonetheless controversial) application of Supreme Court precedent. ${ }^{151}$ The standout feature of the opinion, however, is Posner's conclusion that the statute would be unconstitutional even under rational basis review. ${ }^{152}$ There was no need for Posner to reach this conclusion after determining that the ban was unconstitutional under the more demanding "undue burden" standard from Planned Parenthood of Southeastern Pennsylvania v. Casey. ${ }^{153}$ Yet Posner's supporting arguments for the irrationality of the law enabled him to formulate an approach to laws of this sort that would later be adopted by a Supreme Court majority in Stenberg.

Judge Posner's second partial-birth abortion opinion reached the same conclusion of irrational unconstitutionality as his first, although this time he was in dissent. Sitting en banc, the Seventh Circuit considered the constitutionality of the Wisconsin law held unconstitutional in Planned Parenthood of Wisconsin v. Doyle as well as a similar Illinois statute. ${ }^{154}$ In Hope Clinic v. Ryan, the en banc court held that the Wisconsin and Illinois statutes were both capable of being applied constitutionally, but the court enjoined their application to abortion procedures other than the partial-birth abortion procedure. ${ }^{155}$ Judge Frank Easterbrook wrote the opinion for the court, and Posner penned a dissent. ${ }^{156}$

Judge Posner's Hope Clinic dissent argues for the irrationality of laws whose application turns on the location of the fetus that is killed: "From the standpoint of the fetus, and, I should think, of any rational person, it makes no difference whether, when the skull is crushed, the fetus is entirely within the uterus or its feet are outside the uterus." 157 Because "[n]o reason of policy or morality ... would allow the one [and] would forbid the other," the

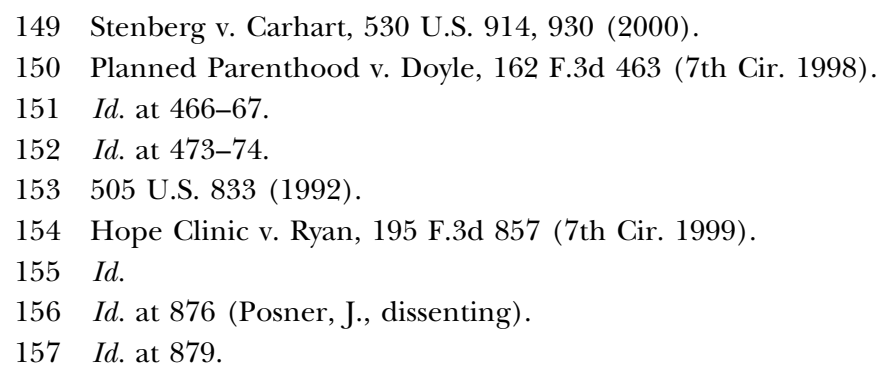


state's reason must be "to dramatize the ugliness of abortion." 158 The legislation was "[w]hipped up by activists," and public support for the laws was based "on sheer ignorance of the medical realities of late-term abortion."159 Those medical realities, as described by Posner in his earlier Doyle opinion, are that " $[a] l l$ abortion procedures, and indeed a vast number of surgical procedures unrelated to the reproductive process, including forms of cosmetic surgery that strike many people as frivolous, are bloody and horrible." 160 Posner's opinion in that case catalogs some of the more macabre aspects of other abortion procedures (e.g., "crushing of the fetus's cranium," reassembling of fetal fragments for assessing completeness of uterine evacuation, "injecting a chemical into the fetus's heart," and "drilling a hole in the fetus's cranium and removing the fetus's spinal fluid through the hole") in support of the claim that "[i]t is difficult to see how anyone acquainted with abortion techniques ... could suppose partial birth abortion more gruesome than the alternatives that Wisconsin has not attempted to prohibit." 161 Rather than an attempt to advance some legitimate state interest (such as maternal health or the promotion of fetal life), Posner describes the Wisconsin and Illinois partial-birth abortion bans as intended primarily to make a "statement . . . in an ongoing war for public opinion, though an incidental effect may be to discourage some late-term abortions."162

The other main thread running through Judge Posner's opinions is the compulsion and constraint of Supreme Court precedent, particularly with respect to the absence of a textual health exception in the statutes. On the need for a health exception, Posner appeals to the consensus of medical opinion in the statement of the American College of Obstetricians and Gynecologists ${ }^{163}$ and criticizes the majority's reliance on two publications by doctors as well as the majority's own statistical analysis: "It is not enough to note that there is some evidence in support of one side of the issue, when there is more evidence on the other side." 164 Posner concludes that "what is at stake . . . is whether the people who feel that way are entitled to coerce a woman who feels differently to behave as they would in her circumstances." 165 Supreme Court precedent dictates one, and only one, answer:

$158 I d$.

159 Id. at 880.

160 Planned Parenthood v. Doyle, 162 F.3d 463, 470 (7th Cir. 1998).

$161 I d$. (citation omitted). In the portion omitted with ellipses in the quotation above, Posner describes these techniques as "lucidly described in Alan F. Guttmacher \& Irwin H. Kaiser, 'The Genesis of Liberalized Abortion in New York: A Personal Insight,' in Abortion, Medicine, and the Law 546, 557-64 (4th ed., J. Douglas Butler \& David F. Walbert eds., 1992)."

162 Hope Clinic, 195 F.3d at 880-81 (Posner, J., dissenting).

163 Id. at 883-84. This group opined that the partial-birth abortion procedure "may be the best or most appropriate procedure in a particular circumstance to save the life or preserve the health of a woman, and only the doctor, in consultation with the patient, based upon the woman's particular circumstances, can make this decision." Id.

$164 I d$. at 885.

$165 I d$. at 890. 
"The Constitution as interpreted by the Supreme Court in decisions that we are not free to palter with answers this question 'no." "166

In contrast with Judge Posner's appeal to a standard of lowest-commondenominator irrationality to condemn a partial-birth ban, Judge Wilkinson appeals to history and to the moral sense of Americans to credit such legislation. Both of Wilkinson's opinions addressing the constitutionality of a partial-birth abortion ban dealt with a Virginia law. In Richmond Medical Center for Women $v$. Hicks, ${ }^{167}$ Wilkinson wrote an opinion concurring in the denial of rehearing en banc after a split panel held the law unconstitutional based on the Supreme Court's invalidation of Nebraska's similar law in Stenberg v. Carhart. ${ }^{168}$ Wilkinson later wrote in support of the opposite conclusion after the Supreme Court upheld a similar federal ban in Gonzales v. Carhart. ${ }^{169}$

Both of Judge Wilkinson's opinions condemn the practice of partialbirth abortion; the difference in outcome is attributed entirely to Supreme Court precedent. Judge Wilkinson's first concurrence has a two-part structure. The first part reflects on the disjunction between morality and constitutional law with respect to abortion and laments the state of the law, characterizing constitutional protection for the partial-birth abortion procedure as "simply and indescribably sad." 170 Wilkinson writes, seemingly in his own voice, that "ending the life of an infant at the moment of its birth is a uniquely disturbing act." 171 But the following sentence is more impersonal: "At the very least, the democratic process should not be precluded from coming to that judgment." ${ }^{172}$ Invoking the New Deal and the Great Society, Wilkinson argues that one function of the democratic process is "to soften the harsh blows of life"173: "I am at a loss to explain how a partially born child can be excluded from the American embrace." 174

The second part of the opinion consists of three sentences: "We do not write upon a clean slate here. As circuit judges, we are bound to follow the

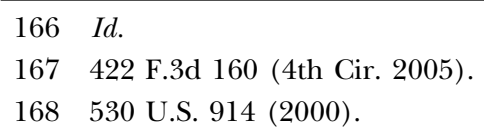

169 Gonzales v. Carhart, 550 U.S. 124 (2007). The Court in Gonzales distinguished the federal statute from the state statute at issue in Stenberg on the ground that it did not reach as broadly, and that a textual health exception was not necessary. Id. at 151-55. On remand after Gonzales, the same panel that first held the Virginia law unconstitutional again found it unconstitutional by the same vote. Richmond Med. Ctr. for Women v. Herring, 527 F.3d 128 (4th Cir. 2008). Upon reconsideration by the Fourth Circuit en banc, however, the court of appeals voted six to five to uphold the law. Richmond Med. Ctr. for Women v. Herring, 570 F.3d 165 (4th Cir. 2009) (en banc). Judge Niemeyer wrote the opinion for the court, and Wilkinson wrote a separate concurring opinion. Id. at 180 (Wilkinson, J., concurring).

170 Hicks, 422 F.3d at 162 (Wilkinson, J., concurring).

171 Id. at 161.

$172 I d$.

173 Id.

174 Id. at 161-62. 
Supreme Court. I can find no fair basis for distinguishing this case from Stenberg v. Carhart. For that reason, I vote to deny rehearing en banc."175

Revisiting the case after remand in Gonzales, Judge Wilkinson's opinion begins by stating that the court should "uphold Virginia's statute because it is similar in critical respects to the federal statute upheld by the Supreme Court." 176 After explaining these similarities, and arguing that a facial challenge to Virginia's statute "was inappropriate from the start," 177 Wilkinson spends the remainder of his opinion addressing institutional competence and the lessons of history. Partial-birth abortion, he writes, "is a brutal business for which we are asked to provide constitutional protection, and nothing in law or precedent requires that we do so." 178 He then considers three time periods_-"past, present, and future"179_to explain his position.

The "past" is comprised of various historical reflections: "It is inconceivable that the founding generation or the drafters of the Fourteenth Amendment thought that their Constitution dealt with the subject of partial-birth abortion." 180 He observes that "our forebears would have been amazed to discover that the Constitution had whisked the issue of partial-birth abortion from the legislative branch and through some mysterious process assigned it to the courts." 181 Protection for partial-birth abortion does not "find a foothold in the ideals of equality and liberation from bondage that motivated the conflict out of which the Fourteenth Amendment grew."182 And "[i]t disrespects our forebears to make such inventions of their intentions and to invoke the greatness of their creation for ending the creation of a life halfway into this world."183

The "present" focuses on the "difficult and intractable"184 nature of the abortion issue, relying on this intractability as a reason against resolving these disputes constitutionally. Because "the very difficulty of the issue commends itself to legislative compromise," Judge Wilkinson criticizes "[t]hose who would strike Virginia's statute as unconstitutional" for granting "little voice" to those opposed to abortion "on an issue where moral, religious, and philosophical beliefs have taken . . . deep root."185

As for the "future," Judge Wilkinson claims that though technical terminology today may "disguise what is happening, in the name of our founding document no less"186:

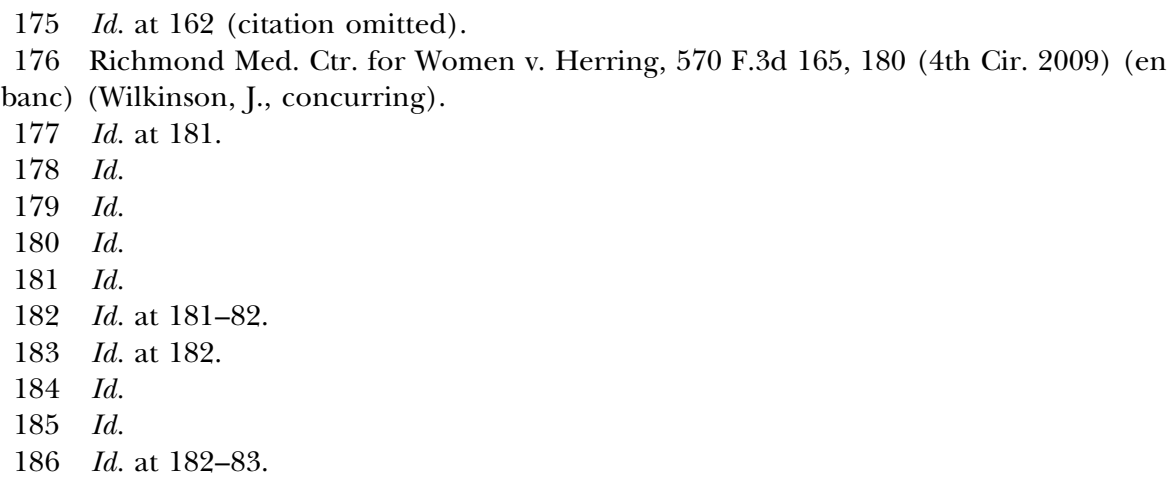


The future, however, will not be similarly misled. The fact is that we-civilized people-are retreating to the haven of our Constitution to justify dismembering a partly born child and crushing its skull. Surely centuries hence, people will look back on this gruesome practice done in the name of fundamental law by a society of high achievement. And they will shudder. ${ }^{187}$

Having invoked the judgment of future generations, Judge Wilkinson qualifies his moral opposition with a familiar argument from judicial restraint: he "would not deny the ability of democratic majorities to sanction [partial-birth abortion] in law."188

The substantive and stylistic contrasts between Judge Posner's and Judge Wilkinson's opinions in this area are striking. Yet both sets of opinions successfully shaped the terms of their legal analysis in ways that were echoed by Supreme Court Justices in subsequent opinions. Not only did Judge Posner's analysis in Hope Clinic prefigure the Supreme Court's holding in Stenberg, but Justice Stevens' Stenberg concurrence explicitly adopted Posner's view that the legislation was "simply irrational" as well as his diagnosis of the legislature's motivations for passing the law. ${ }^{189}$ Justice Ginsburg's concurring opinion (which also explicitly endorses Posner's position) does the same. ${ }^{190}$ By comparison, Judge Wilkinson's morally laden language, not only echoed Justice Kennedy's dissent in Stenberg, but was also resonant in Justice Kennedy's opinion for the Court in Gonzales. These opinions reveal that the influence of legal analysis need not run only from above to below in the federal judicial hierarchy, but that issue-shaping influence can run from below to above as well.

The different outcomes in Stenberg and Gonzales might cause one to conclude, as Posner later did extrajudicially, that the Supreme Court's partialbirth abortion course reversal simply means that the Court is a "political court."191 As it happens, however, the Supreme Court's reasoning in Part IV of Gonzales is largely prefigured by the reasoning in Part III of Judge Easterbrook's majority opinion in Hope Clinic, ${ }^{192}$ so that it is something of an over-

\section{Id. at 183.}

$188 I d$.

189 Stenberg v. Carhart, 530 U.S. 914, 946-47 (2000) (Stevens, J., concurring).

190 Id. at 951-52 (Ginsburg, J., concurring).

191 Posner, supra note 7, at 278 ("[W] hat made the difference in the outcomes of the two cases was not the minor differences between the statutes but the replacement of O'Connor (part of the 5-4 majority in Stenberg) by the more conservative Alito. . ..").

192 Hope Clinic v. Ryan, 195 F.3d 857 (7th Cir. 1999). Judge Easterbrook rejected the facial challenge to the Wisconsin and Illinois statutes' failure to include an explicit health exception by reading the Casey language about the importance of a statutory exception for "the woman's life or health" not as "a universal rule, one applicable even when the procedure in question lacks demonstrable health benefits." Id. at 871 . He wrote that "when state law offers many safe options to [obtain pre-viability abortions,] the regulation of an additional option does not produce an undue burden." Id. This was the position adopted in Gonzales. See Gonzales v. Carhart, 550 U.S. 124, 164-65 (2007) (holding that "the Act does not require a health exception" because "[a]lternatives are available to the prohibited 
statement to conclude that the sole factor explaining the Supreme Court's decision in Gonzales was a change in personnel. Or, stated differently, if the Supreme Court's decision in Gonzales shows it to be a "political court," then it is political in a manner that, at the circuit court level, is legal.

Indeed, even if one finds some merit in Judge Posner's claim that the Supreme Court is a "political court," one might equally conclude that the intermediate appellate courts are not "political courts" in the same way because of their distinctive position within the judicial hierarchy. One way to understand Posner's extrajudicial description of the Supreme Court's partialbirth abortion decisions as "political" is as a sotto voce criticism of the Court's treatment in Gonzales of his own judicial (i.e., legally and institutionally constrained) reading of the logical and sensible reach of Casey. As a piece of judicial-rather than political or theoretical—writing, Posner surely believed that he had offered the superior product: "Kennedy's attempt to distinguish Stenberg was so unconvincing that it makes one think that when he said in Casey that overruling weakens the Court, he meant that only acknowledged overruling has that effect."193

Judge Wilkinson's opinions hewed more closely to the Supreme Court's ultimate resting place in Gonzales. But the fact that Gonzales vindicated the position of his dissenting colleagues in the first denial of en banc rehearing suggests that Wilkinson was actually freer in that case to uphold Virginia's law than his opinion in support of the denial of rehearing reflected. Even so, institutional and role-based constraints explain Wilkinson's vote to deny rehearing notwithstanding his morally and emotionally charged complaints about the state of the law. Justice Kennedy's opinion for the Court in Gonzales includes some of the same types of moral and emotionally fraught judgments, ${ }^{194}$ but Kennedy had the ability to use those moral judgments to shape constitutional law in a way that Wilkinson did not. Once the Supreme Court legalized these considerations, but only at that point, Wilkinson was liberated to follow its lead and expand on his previous misgivings with a more developed discussion which manifests his distinctive restraintism, one which depends on democratic as well as nationalist premises. ${ }^{195}$

procedure"). Similarly, Judge Easterbrook held that where there was expert testimony on both sides of a disputed medical issue, courts should defer to a state's legislative choices. Hope Clinic, 195 F.3d at 873. Again, this was the view adopted in Gonzales. See Gonzales, 550 U.S. at 164.

193 Posner, supra note 7, at 278. Posner is not the only federal appellate judge to have expressed dissatisfaction with the Supreme Court's judicial craftsmanship. See, e.g., Benjamin Wittes, Without Precedent, AtLantic Monthly, Sept. 2005, at 39, available at http://www .theatlantic.com/magazine/archive/2005/09/without-precedent/304161/ (describing some of these complaints).

194 See Gonzales, 550 U.S. at 158-59 (crediting Congress's apparent conclusion that "the type of abortion proscribed by the Act requires specific regulation because it implicates additional ethical and moral concerns that justify a special prohibition," and stating that "[r] espect for human life finds an ultimate expression in the bond of love the mother has for her child").

195 See supra Section I.B. 


\section{Perceived Official Favoritism of Christianity}

Our final comparison focuses on two relatively recent Establishment Clause opinions by Judges Posner and Wilkinson involving perceived official favoritism of Christianity. Both of the opinions precede the Supreme Court's decision last term in Town of Greece $v$. Galloway, which reaffirmed the constitutionality of legislative prayer. ${ }^{196}$ Yet the Court's historically oriented test in Town of Greece provides a useful comparison with the opinions of Posner and Wilkinson in this area. All three reflect doctrinally controlled and substantively narrow readings of the Establishment Clause, but stylistically the opinions are different from one another.

In Doe v. Elmbrook School District, Posner dissented from an en banc opinion of the Seventh Circuit holding that a school district violated the Establishment Clause by holding high school graduations at a Christian church. ${ }^{197}$ In Joyner v. Forsyth County, ${ }^{198}$ Wilkinson wrote an opinion for a split panel of the Fourth Circuit holding that a county board violated the Establishment Clause by inviting area clergy on a rotating basis to offer opening prayers at meetings when the resulting pattern of prayers was heavily weighted toward explicitly Christian invocations. While the decisions exhibit different approaches to the Establishment Clause, interpretive and role-related factors are intertwined in both, and institutional factors are at least as important as the judges' interpretive theories in their decisionmaking process. Their decisions as judges are not best explained by reference to their theories of pragmatism or restraint, but rather by reference to their situated understandings of the relevant legal materials.

Doe v. Elmbrook School District arose out of a school district's decisions to hold high school graduations and related programs at Elmbrook Church, a nondenominational Protestant Christian "megachurch"199 with a spacious sanctuary. The choice of location was prompted in part by overwhelming student votes to hold graduation at the church instead of a cramped and uncomfortable gymnasium. A seven-judge en banc majority of the Seventh Circuit held that the location of the graduation ceremonies impermissibly endorsed religion and resulted in religious coercion. ${ }^{200}$ Judge Posner dissented. ${ }^{201}$

Judge Posner's dissent leads with the text of the Establishment Clause and a curt discussion of its history, both of which "provide no clue" about the permissibility of public school graduations in religious buildings. ${ }^{202}$ Posner then moves to a heavily critical discussion of the "formless, unanchored, [and] subjective" doctrine that the Supreme Court "has heaped on the

196 Town of Greece v. Galloway, 134 S. Ct. 1811 (2014).

197 Doe v. Elmbrook Sch. Dist., 687 F.3d 840 (7th Cir. 2012).

198 Joyner v. Forsyth Cnty., 653 F.3d 341 (4th Cir. 2011).

199 Elmbrook Sch. Dist., 687 F.3d at 873 (Posner, J., dissenting).

$200 I d$. at 856 ( majority opinion).

201 Id. at 872 (Posner, J., dissenting). Judges Easterbrook and Ripple also authored dissents.

202 Id. 
defenseless text of the establishment clause."203 He relies on dissenting and concurring opinions of Justice Thomas (criticizing the "endorsement test") and Justice Scalia (criticizing the test in Lemon v. Kurtzman) to underscore that even certain members of the Supreme Court share his skepticism. ${ }^{204}$

Despite his dissatisfaction with the doctrine, Judge Posner discusses it at length. He associates the Court's principle that "all creeds must be tolerated and none favored" 205 with Edward Gibbon's aphorism that

The judge should not be concerned with the truth or falsity of any religious faith but should regard the various faiths as "equally useful" from the standpoint of society, in recognition of the importance Americans attach to religion, the diversity and intensity of their religious beliefs and observances, and the bitterness and strife that the government's taking sides among competing faiths would engender. ${ }^{206}$

He observes that "purely secular considerations, such as seating capacity, comfort, location, and price, may well have made the church the best alternative to the school's gym." 207 The graduation ceremony itself was entirely secular as well: Posner distinguishes Lee v. Weisman, Santa Fe Independent School District v. Doe, and Stone v. Graham on the ground that in those cases religion was part of the substance of the proceedings. ${ }^{208}$ Though he acknowledges the presence of religious imagery and literature in the church, ${ }^{209}$ there is no evidence that school officials "endorsed" anything relating to religion, ${ }^{210}$ another tacit affirmation of the Supreme Court's favored approach to this issue.

From the perspective of purely pragmatic adjudication, Judge Posner's emphasis on text, history, and doctrine is somewhat unexpected. Textual fidelity and historical inquiry tend not to be methods that pragmatists favor, at least not above other interpretive tools; ${ }^{211}$ yet here, these considerations lead the opinion and appear to assume lexical priority over other interpretive methods. That is, not only are text and history included in the dissent, and not only do they take pride of place, but it is only because text and history do not foreclose recognition of other values or materials-indeed, only because text and history provide little assistance at all-that Posner is liberated to

203 Id.

204 Id. (citing Utah Highway Patrol Ass'n v. Am. Atheists, Inc., 132 S. Ct. 12 (2011) (Thomas, J., dissenting from the denial of certiorari)); Lamb's Chapel v. Ctr. Moriches Union Free Sch. Dist., 508 U.S. 384, 398-99 (1993) (Scalia, J., concurring)).

205 Lee v. Weisman, 505 U.S. 577, 590 (1992).

206 Elmbrook Sch. Dist., 687 F.3d at 873 (Posner, J., dissenting).

207 Id. at 874.

208 Id. at $874-75$.

209 Id. at 876-77.

$210 I d$. at 874 ("[T] here is no evidence that school officials endorsed or encouraged this or any other religious activity during the graduation.").

211 See John Manning, Constitutional Structure and Statutory Formalism, 66 U. CHI. L. REv. 685, 694-95 (1999) ("Antiformalists believe that when a clear text produces a result plainly at variance with the overall policy of the legislation, judges should adapt the specific text to its ultimate purpose."). 
range over more conventionally pragmatic considerations later in the opinion. ${ }^{212}$ The prominent position of textual and historical factors in this dissent-where, in theory, Posner might feel freer to ignore those interpretive methods that he discounted-is noteworthy. Yet Posner's emphasis on text and history and their position within the opinion are unsurprising when one remembers that Posner is not writing here as a constitutional theorist. His self-understanding of his own role demands that he situate his views within the discursive and interpretive practices of a court that is bound by a higher authority, even when he writes only for himself. ${ }^{213}$

The relationship of Judge Posner's reliance on precedent to judicial pragmatism is more complicated. There is the usual definitional question lurking here involving the range of interpretive tools at the pragmatist's disposal. Posner has stated repeatedly that pragmatists follow text and precedent-indeed, that pragmatic judges "ordinarily ... treat text and precedents as the most important materials of judicial decision." ${ }^{214}$ While an emphasis on the bindingness of precedent to the exclusion of other interpretive methods might suggest a departure from pragmatism, that is certainly not Posner's approach here. Perhaps Posner has only tactical reasons for giving such prominence to precedential arguments, though at least one of the reasons for a strategic emphasis on precedent-to win over colleagues to his opinion-does not obtain here.

The balance of the dissent is laced with more conventionally pragmatic language and argument. Judge Posner discusses the absence of systematic study of the psychological or sociological effects of religious language and symbolism on teenagers ${ }^{215}$ and criticizes the judicial armchair empiricism that characterizes Establishment Clause jurisprudence. ${ }^{216} \mathrm{He}$ is skeptical of the plaintiffs' claim of psychological coercion and the doctrine on which it is based, describing it as "florid hyperbole" and "whistling in the dark." 217 The most likely consequences of the majority's decision are

first, to confirm the view of many religious Americans that the courts are hostile to religion; second, to infuriate students and their families by depriving them of the best site for their high school graduation ... ; and third, to

212 See Elmbrook Sch. Dist., 687 F.3d at 872-78 (Posner, J., dissenting).

213 One might argue that Posner only refers to text and history because he knows that they are inadequate guides, and so referring to them does not interfere with the real grounds of his decision, which come later. But a reading that makes better sense of his reliance on text and history in other cases is that for Posner, these factors (as well as precedent) strongly recommend a certain outcome, and though he does not stop there, text and history represent the first building block toward reaching his disposition.

214 Posner, LAw, supra note 40, at 63.

215 Elmbrook Sch. Dist., 687 F.3d at 873 (Posner, J., dissenting).

216 Id. (citing Michael Heise \& Gregory C. Sisk, Religion, Schools, and Judicial Decision Making: An Empirical Perspective, 79 U. CHI. L. Rev. 185 (2012); Gregory C. Sisk \& Michael Heise, Ideology "All the Way Down"?: An Empirical Study of Establishment Clause Decisions in the Federal Courts, 110 Mich. L. Rev. 1201 (2012)) ("[J]udges inevitably fall back on their . . beliefs based on personality, upbringing . . . and so forth . . ..”).

217 Id. at 876. 
initiate what federal law does not need: a jurisprudence of permissible versus impermissible rentals of church space to public schools and other public entities. $^{218}$

Is Judge Posner's Elmbrook dissent an exemplar of judicial pragmatism? Posner once described Justice Breyer's concurring opinion in Van Orden $v$. Perry-one of two companion cases decided by the Supreme Court that involved the state-sponsored display of Ten Commandments monuments-as distinctively pragmatic. ${ }^{219}$ Yet Breyer's opinion depends upon particularistic judgments about the monument's placement, aesthetic surroundings, and comparatively long history within the community without complaint-all factors that Breyer argued distinguished the monument in the Court's other Ten Commandments case, McCreary County v. ACLU. ${ }^{220}$

These are the very features of Breyer's opinion that Posner praises as pragmatic extrajudicially ${ }^{221}$ and yet also severely criticizes in his Elmbrook dissent. Posner believes that the majority in Elmbrook is creating a "jurisprudence of church furnishings" in which a constitutional violation will depend on courts' detailed inventories of church interiors. ${ }^{222}$ Yet these particularistic and fact-specific aesthetic assessments are some of the very features of Justice Breyer's Van Orden concurrence that, in Posner's view, exemplify pragmatic adjudication. ${ }^{223}$ If Breyer's Van Orden concurrence and Posner's Elmbrook dissent are both examples of judicial pragmatism, then something other than judicial pragmatism is needed to explain the differences between them.

It would be wrong, however, to conclude that the tension between Judge Posner's praise of Justice Breyer's position in the Ten Commandments cases and his Elmbrook dissent demonstrates that the latter is not at all a pragmatic opinion. In part it surely is. Posner spends long sections of the dissent discussing plainly pragmatic considerations: the factual basis for making judgments about psychological coercion; ${ }^{224}$ the lack of reliable empirical data on these issues; ${ }^{225}$ the likely effects of a decision against the church; ${ }^{226}$ and the association of state approval of religion with the weakening of religious fervor. ${ }^{227}$

But it is not pragmatic all the way down. Or, stated differently, legal pragmatism incorporates nonpragmatic considerations in a way that a purer form of pragmatism would not. Judge Posner's dissent does contain features

218 Id. at 877.

219 See Posner, supra note 7, at 320.

220 Van Orden v. Perry, 545 U.S. 677, 703 (2005) (Breyer, J., concurring in the judgment).

221 See Posner, supra note 7, at 322-23.

222 Elmbrook Sch. Dist., 687 F.3d at 878 (Posner, J., dissenting).

223 See Posner, supra note 7, at 322-23.

224 Elmbrook Sch. Dist., 687 F.3d at 876 (Posner, J., dissenting).

225 Id. at 873.

226 Id. at $877-78$.

227 Id. at 878. 
of "everyday pragmatism,"228 but everyday pragmatism is an insufficient explanation for it. As Posner has put it: "[t]he case for legal pragmatism is based not on philosophical argument but on the needs and character of American law." 229 Yet this reference to American law brings to light that the needs and the character of American law in turn depend on institutional qualities that are not typically associated with pragmatism-at least not of the more full-fledged, academic, or pure strains of pragmatism. They include "legalist" methods which sound in text and history; the general preference for "narrow" over "broad" grounds of decision; and a detailed accounting of precedent (even if only for "forward looking" reasons). ${ }^{230}$ Posner has described the "good pragmatist judge" as a "constrained pragmatist." 231 The constraints, however, relate especially to institutional and role-based considerations. Perhaps a better description of Posner's Elmbrook dissent is that it represents what one might call "pragmatic constraintism." The constraints, not the pragmatism, control the opinion.

These constraints are particularly important for intermediate appellate judges because their institutional commitments require them, on the one hand, to apply and (at times) extend Supreme Court precedent, and, on the other, to give district courts guidance. Judge Posner describes this phenomenon in the writing of Jerome Frank: "The difference between a constrained and an unconstrained pragmatist is well illustrated by Jerome Frank in his twin roles as bomb-throwing legal realist and Second Circuit judge. He did not abandon legal realism on the bench, but he curbed it; his judicial opinions are well within the mainstream." 232

Judge Wilkinson's approach to the Establishment Clause in Joyner v. Forsyth County also straddles the divide between what he describes as a restraintist theory of constitutional interpretation and institutional or role-based considerations. ${ }^{233}$ Just as Judge Posner's Elmbrook dissent is not unequivocally pragmatic, there is much in Wilkinson's majority opinion in Joyner that is not explained by a theory of judicial restraint.

The Fourth Circuit's decision in Joyner held unconstitutional as applied the prayer policy of the Forsyth County, North Carolina, Board of Commissioners. ${ }^{234}$ The Board's policy was to invite area religious leaders to deliver a prayer before board meetings. ${ }^{235}$ The invited leaders were of many faiths, and they were slotted to pray on a first-come, first-serve basis. ${ }^{236}$ The invitation requested "that the prayer opportunity not be exploited as an effort to convert others to the particular faith of the invocational speaker, nor to dis-

228 Posner, LAw, supra note 40, at 4 (internal quotation marks omitted).

229 PosNer, supra note 7, at 233.

$230 \quad I d$. at $246-47$.

231 Id. at 253.

232 Id. at 254.

233 Joyner v. Forsyth Cnty., 653 F.3d 341 (4th Cir. 2011).

234 Id. at 355.

235 Id. at 356.

$236 I d$. 
parage any faith or belief different than that of the invocational speaker."237 The Board formalized a written prayer policy after its practices had been challenged in court. ${ }^{238}$ The policy's stated goal was to "'acknowledge and express the Board's respect for the diversity of religious denominations and faiths represented and practiced among the citizens of Forsyth County." "239

Judge Wilkinson's majority opinion is structured as a straightforward application of Supreme Court and Fourth Circuit precedent. It begins by acknowledging that the Supreme Court has upheld the practice of prayer at the opening of legislative sessions based largely on the fact that legislative prayer " "is deeply embedded in the history and tradition of this country." "240 Summarizing Supreme Court and Fourth Circuit decisions, Wilkinson writes that "invocations at the start of legislative sessions can solemnize those occasions; encourage participants to act on their noblest instincts; and foster the humility that recognition of a higher hand in human affairs can bring."241 A "clear line of precedent not only uphold[s] the practice of legislative prayer, but acknowledge[es] the ways in which it can bring together citizens of all backgrounds and encourage them to participate in the workings of their government." 242

The opinion thereafter cautions that "both the Supreme Court and this circuit have been careful to place clear boundaries on invocations" because of the risks posed by prayer in governmental settings. ${ }^{243}$ Prayer "can create an environment in which the government prefers-or appears to preferparticular sects or creeds at the expense of others" and it "has the potential to generate sectarian strife" that "does violence to the pluralistic and inclusive values that are a defining feature of American public life." 244 Therefore, legislative prayers must "embrace a non-sectarian ideal"- "that those of different creeds are in the end kindred spirits, united by a respect paid higher providence and by a belief in the importance of religious faith." ${ }^{245}$ Wilkinson distills from Supreme Court and Fourth Circuit precedent the following test: "Infrequent references to specific deities, standing alone, do not suffice to make out a constitutional case. But legislative prayers that go furtherprayers in a particular venue that repeatedly suggest the government has put its weight behind a particular faith-transgress the boundaries of the Establishment Clause."246

Judge Wilkinson's application of this test supported the court's holding that the County's implementation of its prayer policy was unconstitutional. ${ }^{247}$

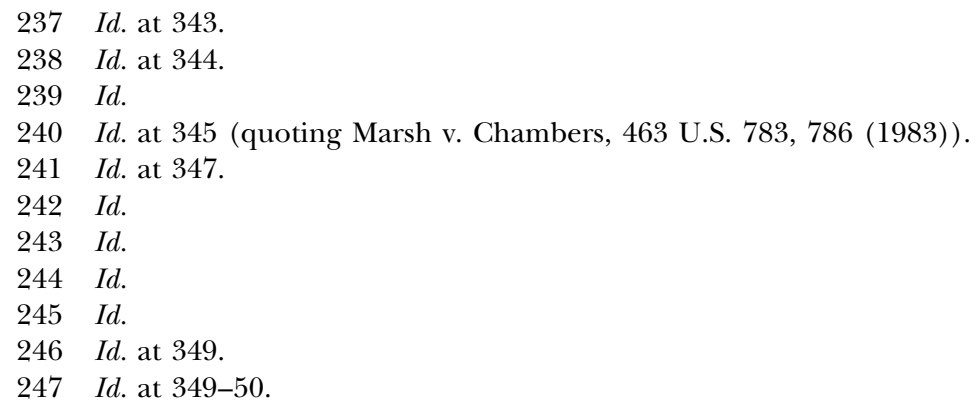


One of the prayers at a Board meeting "discussed specific tenets of the Christian religion," and approximately eighty percent of the prayers over the course of more than a year and a half "referred to Jesus, Jesus Christ, Christ, or Savior." 248 Taken together, the prayers during the time period covered by the complaint "did not 'evoke common and inclusive themes." 249 Judge Wilkinson distinguished prior circuit precedent permitting legislative prayers on the ground that the key feature in those cases "was the non-sectarian nature of the prayer." 250 And he interpreted the Supreme Court's dictum in Marsh that courts should not " "parse the content of a particular prayer" "251 to mean not that courts ought to shut their eyes to "patterns of sectarian prayer in public forums," but rather that they "should not be in the business of policing prayers for the occasional sectarian reference."252 “[C]itizens," he concludes, "should come to public meetings confident in the assurance that government plays no favorites in matters of faith but welcomes the participation of all," an assurance that the Board failed to provide. ${ }^{253}$

Judge Wilkinson has written extrajudicially that judicial restraint favors deference to "the [d]emocratic [w]ill" 254 and "judicial noninvolvement in intense political controversy." 255 Or, as Judge Posner has put it, the restrained judge is "highly reluctant to declare legislative or executive action unconstitutional."256 Because the Fourth Circuit's decision struck down a longstanding practice that had been implemented by a local, democratically elected body, ${ }^{257}$ Joyner is not a decision exemplifying the type of restraint that counsels deference to democratic majorities. Nevertheless, a policy of judicial restraint is not tantamount to abdication to majority sentiment, particularly if Supreme Court or Fourth Circuit precedent demanded otherwise. Judicial restraint requires rigorous adherence to vertical and horizontal stare decisis. ${ }^{258}$

Supreme Court precedent did not require this result. ${ }^{259}$ But the decision followed logically (though not inexorably) from Fourth Circuit prece-

\section{Id. at 349.}

249 Id. at 350 (quoting Simpson v. Chesterfield Cnty. Bd. of Supervisors, 404 F.3d 276, 287 (4th Cir. 2005)).

$250 \quad I d$. at 351.

251 Id. at 351 (quoting Marsh v. Chambers, 463 U.S. 783, 795 (1983)).

$252 I d$.

253 Id. at 355.

254 WiLkinson, supra note 4, at 20.

$255 I d$. at 58.

256 Posner, supra note 40, at 521.

257 Joyner, 653 F.3d at 355.

258 See Wilkinson, supra note 91, at 255 (discussing "the solemn duty of judges on the inferior federal courts to follow ... decisions with which [those judges] may not agree"). 259 Marsh v. Chambers, 463 U.S. 783 (1983), which was reaffirmed and in some ways extended in Town of Greece v. Galloway, 134 S. Ct. 1811 (2014), upheld a legislative prayer policy and practice less neutral and inclusive than Forsyth County's. The policy in Marsh provided that the Nebraska legislature would choose the prayer and that a paid government employee-in this case, the same Presbyterian minister over a period of sixteen years-would deliver it. Marsh, 463 U.S. at 784-85; see also id. at 800 n.9 (Brennan, J., 
dent interpreting the Supreme Court's decision in Marsh v. Chambers and County of Allegheny $v$. ACLU to permit nonsectarian legislative prayer consistent with an inclusive "civic faith." In a similar legislative prayer case seven years earlier, ${ }^{260}$ Judge Wilkinson's opinion for the court committed the Fourth Circuit to an extension of Marsh that he and Judge Keenan later found controlling in Joyner. ${ }^{261}$

Depending on the doctrinal particulars, the decision of a lower court to apply a legal principle that extends beyond the earlier decisions from which it has been extracted can be understood as a form of judicial restraint. This is the type of institutional restraint on display in Judge Posner's Second Amendment decision discussed earlier, for example. ${ }^{262}$ Yet the exercise of this traditional judicial function cannot reliably be expected to lead to results that a theory of judicial restraint (in the democratically deferential sense) requires. The truest description of Joyner is not that it is restrained in that sense, but that it is not an implausible extension of Marsh as filtered through the County of Allegheny dictum and the Fourth Circuit's prior decisions. Whether Joyner is persuasive depends on evaluating these moves within the distinctive practice of judging, not on its conformity to a general theory of judicial restraint.

\section{From Theory to Disposition}

We step back now and take a broader view. Part I of this Article focused on the critical dimension of Judge Posner's and Judge Wilkinson's thought-

dissenting) (protesting the prayers' frequent "Christological references"). The policy in Joyner permitted leaders from a diverse group of religious institutions an equal opportunity to deliver an invocation, speakers were self-selected and unpaid, and Forsyth County exercised no control over the content of the prayers. Joyner, 653 F.3d at 343-45. Judge Wilkinson's claim that the Marsh Court "took care to emphasize" the "inclusive" character of the prayers offered before the Nebraska legislature, 653 F.3d at 347, extends Marsh: Marsh spoke specifically in terms of non-proselytism and non-advancement, but it did not state that the only permissible legislative prayers were "inclusive" prayers. See Marsh, 463 U.S. at 792. Yet Judge Wilkinson's opinion is hardly disconnected from Supreme Court precedent either. The Joyner court's holding is premised on a reading of certain dicta in County of Allegheny v. ACLU, a case involving the state-sponsored display of religious symbols, where the Supreme Court stated that the "legislative prayers involved in Marsh did not violate this principle [of government non-affiliation with "one specific faith"] because the particular chaplain had 'removed all references to Christ." Cnty. of Allegheny v. ACLU, 492 U.S. 573, 603 (1989) (quoting Marsh, 463 U.S. at 793 n.14). For further discussion of the Supreme Court's Establishment Clause doctrine, see Marc O. DeGirolami, The Tragedy of Religious Freedom (2013).

260 Simpson v. Chesterfield Cnty. Bd. of Supervisors, 404 F.3d 276 (4th Cir. 2005).

261 See Joyner, 653 F.3d at 348-49 (explaining that Simpson reaffirmed the principle that controlled Joyner's outcome). This assessment of Simpson's effect was not shared in Joyner by another Fourth Circuit judge who joined Judge Wilkinson's opinion for the court in Simpson. Judge Niemeyer contended in his Joyner dissent that a careful reading of Simpson underscores the difficulty of distinguishing "sectarian" from "ecumenical" prayers. See Joyner, 653 F.3d at 365 (Niemeyer, J., dissenting).

262 Moore v. Madigan, 702 F.3d 933 (7th Cir. 2012). 
their criticisms of constitutional theory. Each objects to "top-down" or "cosmic" theories and theories that leave no room for the exercise of judicial discretion (Posner's term) or judicial wisdom (Wilkinson's term). But their thought also has a constructive dimension: Posner embraces judicial pragmatism while Wilkinson champions judicial restraint. And Part II examined various ways in which the judges wove these commitments into their decisions in constitutional cases even as it highlighted the limited influence of judicial pragmatism and judicial restraint in these cases.

This final Part explores broader questions about the relationship between constitutional theory and the judicial role in federal constitutional law. Rather than offering constitutional theories of interpretation or adjudication that directly rival other such theories, these judges' antitheoretical views are better understood as making a different point altogether about constitutional adjudication. They are describing and advocating a particular set of dispositions toward the judicial office. Pragmatism and restraint are for them not theories of constitutional interpretation or adjudication but qualities of judicial excellence. After explaining how and why this represents an improved understanding of the judges' extrajudicial contributions, we argue that each judge's account of the ideal judicial disposition toward constitutional adjudication is nevertheless flawed. We then conclude with a discussion of another intermediate federal appellate judge, Henry Friendly. Judge Friendly's example more nearly approaches the ideal qualities of judicial disposition and judicial duty in constitutional adjudication than other judicial paragons championed by Posner and Wilkinson.

\section{A. Evaluating the Theory Disclaimer}

Although both judges deny offering a theory of their own, Judge Posner and Judge Wilkinson do present their approaches as rivals to what they perceive as the defective offerings of academic constitutional theory: judges should not be originalists, but pragmatists; judges should not be living constitutionalists, but devotees of judicial restraint; and so on. Yet the doctrinal study in Part II suggests that neither judicial pragmatism nor judicial restraint provides reliable practical guidance in the very kinds of cases in which one would expect constitutional theory to play a more prominent if not decisive role. Put another way, their approaches at work offer no clear answers to fill the blank spaces in the following: "all else being equal, judicial pragmatism counsels a judge to , while judicial restraint counsels a judge instead to

To the extent that judicial pragmatism and judicial restraint are offered as replacements for constitutional theories such as originalism or Dworkinian moralism, then, they must be judged as failures. Their core ideas are too slippery, their substance too hard to pin down, and their guidance too inconsistent. As constitutional theories, they are therefore vulnerable to the sorts 
of objections directed against them by many academic theorists. ${ }^{263}$ In a recent example of such criticism, Dean Erwin Chemerinsky claims that Judge Wilkinson's antitheoretical complaints are "profoundly wrong because there is simply no way to avoid a constitutional theory in deciding, or having views on, constitutional issues."264 Surely Chemerinsky is right that "having views" about constitutional interpretation is important if one is making decisions about the meaning of the Constitution.

And yet it manifests a certain myopia for Dean Chemerinsky to criticize Judge Wilkinson for failing to offer a viable replacement for academic theories of constitutional interpretation. Academic refinements in constitutional theory often outpace both judicial uptake and judicial objections, and this is to be expected in light of the different tasks of theory and practice and the perennial separation between them. Furthermore, criticisms of this kind miss what is valuable in Wilkinson's and Posner's antitheoretical approaches. Judges' extrajudicial criticisms of academic constitutional theory and their own contributions to it provide windows on the larger world of constitutional adjudication that offer distinctive lines of vision into the qualities of judicial duty and judicial excellence. These insights-insights that concern dispositions and attitudes, not theories-come into focus by comparing what they say (extrajudicially) with what they do (judicially).

We ought therefore largely to credit Judge Posner's and Judge Wilkinson's theory disclaimers. They are not offering theories of constitutional interpretation or adjudication. If they are offering any kind of theory-any fixed set of general propositions that describes or guides a practice-it is a theory not of constitutional interpretation, but of excellence in judging. But in fact, judicial pragmatism and judicial restraint are not sets of fixed propositions at all, and certainly not the kinds of propositions that are offered by originalism or Dworkinian moralism. Those theories prescribe particular

263 For a selection of academic critiques of Wilkinson, see David Rudenstine, Self-Government and the Judicial Function, 92 Tex. L. Rev. 161 (2013) (reviewing WiLkinson, supra note 4); see also Nelson Lund, The Cosmic Mystery of Judicial Restraint, 14 ENGAGE: J. FederAList Soc'y Prac. Groups 100 (2013); Zachary Baron Shemtob, Book Review, 22 L. \& Pol. Bоок Rev. 162 (2012), available at http://www.lpbr.net/2012/04/cosmic-constitutionaltheory-why.html (reviewing WiLkinson, supra note 4); Jeffrey Rosen, Against Interpretation, N.Y. Times, Mar. 16, 2012, http://www.nytimes.com/2012/03/18/books/review/cosmicconstitutional-theory-by-j-harvie-wilkinson-iii.html; Mark Graber, On Cosmic Constitutional Theory, Balkinization, (Feb. 21, 2012, 8:36 PM), http://balkin.blogspot.com/2012/02/oncosmic-constitutional-theory.html;. But see Marc O. DeGirolami, Astral Appetites, New Republic, (Sept. 5, 2012), http://www.newrepublic.com/book/review/cosmic-constitution al-theory-judicial-restraint (criticizing attempts to describe judicial restraint as "its own kind of constitutional theory").

The critical literature on Posner's pragmatism is voluminous (although there is no comparative study like that set forth in this Article). For a recent, insightful exploration of Posnerian pragmatism with extensive citations to and discussions of other critical examinations, see Edward Cantu, Posner's Pragmatism and the Turn toward Fidelity, 16 Lewis \& Clark L. Rev. 69 (2012).

264 Erwin Chemerinsky, The Inescapability of Constitutional Theory, 80 U. CHI. L. Rev. 935, 937 (2013). 
activities and procedures for ascertaining meaning and rendering decisions: ascertain and fix the original public meaning of a legal text (originalism), or develop the best principled basis for a decision by attending to the dimensions of fit and justification (Dworkinian moralism). Judicial pragmatism and judicial restraint do not provide explicit guidance of this sort. They treat the underlying activity as the practice of judging and then offer vague prescriptions for the manner in which to undertake that activity. Pragmatism and restraint therefore can and should be understood in adverbial terms, as modifiers for a particular activity-the practice of judging. ${ }^{265}$ The good judge in a constitutional case is the one who judges pragmatically or restrainedly.

But it is excellence in the practice of judging that is the judges' primary concern. Writing extrajudicially not only helps them to clarify the nature of that excellence but also allows them to state their respective cases for it. Understood as descriptions of dispositions characteristic of judicial excellence, judicial pragmatism and judicial restraint are not subject to the same categories of criticism either leveled at the judges' approaches by most academic critics or leveled by the judges against academic theories of constitutional interpretation. Unlike those theories, judicial pragmatism and judicial restraint do not purport to offer direct how-to guidance (as originalism does) or "one right answer" to constitutional questions (as Dworkinian moralism does). Instead, the qualities of judicial excellence championed by these judges are better characterized as proper dispositions toward constitutional adjudication-as general orientations to constitutional law that Posner and Wilkinson believe will produce reasonable and sensible decisions.

\section{B. Portraits of Judicial Excellence}

Understanding judicial pragmatism and judicial restraint adverbially-as describing a disposition toward judging rather than as a substantive theoryhelps to distinguish them as different in kind from such theories as originalism or Dworkinian moralism. But it also brings into focus an important methodological tool that both judges use repeatedly to develop and explain their views: recourse to certain exemplary (and non-exemplary) judges of the past and present. In fact, Posner and Wilkinson frequently offer critical evaluations of other judges-discussing, assessing, and comparing their own thought about constitutional adjudication to that of their subjects. These are often useful and illuminating exercises in judicial self-reflection. As Posner has put it, " $[\mathrm{w}]$ hen one considers that the appellate judge is the central figure in Anglo-American jurisprudence, the dearth of evaluative writing on

265 Cf. Timothy Fuller, Michael Oakeshott on the Rule of Law and the Liberal Order, LibraRY OF LAw \& LiberTy (Sept. 2, 2012), http://www.libertylawsite.org/liberty-forum/michaeloakeshott-on-the-rule-of-law-and-the-liberal-order/ (describing Michael Oakeshott's account of the expression "rule of law" as standing "for a mode of moral association exclusively in terms of the recognition of the authority of known, noninstrumental rules (that is, laws) which impose obligations to subscribe to adverbial conditions in the performance of the self-chosen actions of all who fall within their jurisdiction"). 
individual judges that is at once systematic, nonpolitical, and nonpolemical is remarkable."266 And indeed, judicial intellectual portraiture has been a major subject in Posner's extrajudicial writing.

Yet the importance of the judges' focus on critical judicial biography and comparative judicial evaluation can be missed because Posner and Wilkinson sometimes pitch their contributions as substitutes for academic constitutional theory rather than accounts of dispositions or character traits that appertain to judicial excellence. Consider for example Posner's and Wilkinson's respective denunciations of Justice Scalia's opinion for the Court in D.C. v. Heller. ${ }^{267}$ Each uses the occasion to criticize originalism. ${ }^{268}$ Yet in criticizing the Heller opinion as exemplifying the intrinsic failures of originalism, neither Posner nor Wilkinson engages with the broad range of academic originalist scholarship that remains untouched by their objections to Heller. Suppose, for example, that Posner is right that Scalia's analysis in Heller suffers from the defect of "disregard for the interpretive conventions of the legal culture" (scholarly opinion on this seems mixed). ${ }^{269}$ As a criticism of originalist theory, the objection falls flat: the idea that "disregard for the interpretive conventions of the legal culture" in which constitutional provisions were drafted and ratified is endemic to textual originalism is easily falsified. ${ }^{270}$ Likewise, Wilkinson contends that "originalism has failed to deliver on its promise of restraint," ${ }^{271}$ and he uses Heller as an example: "While Heller can be hailed as a triumph of originalism, it can just as easily be seen as the opposite-an exposé of original intent as a theory no less subject to judicial subjectivity and endless argumentation as any other." ${ }^{272}$ But as a criticism of originalist theory, the blanket indictment is unwarranted. Wilkinson seems unaware that leading contemporary academic originalists argue for originalism on other grounds and have disclaimed the promise of tight judicial constraint as a reason to adopt originalism. ${ }^{273}$

The failure to discuss the full breadth of originalist theory in the academic literature would be devastating if the judges' criticisms were truly

266 Richard A. Posner, Cardozo: A Study in Reputation viii (1990); see also Posner, supra note 7, at 256-62 (listing several examples); Posner, supra note 43; WiLkinson, supra note 4, at 110; Wilkinson, supra note 98, at 166; Wilkinson, supra note 59, at 795-96.

267 District of Columbia v. Heller, 554 U.S. 570 (2008).

268 See, e.g., Posner, supra note 13, at 193; Wilkinson, supra note 4, at 58.

269 Posner, supra note 13, at 193.

270 See, e.g., John O. McGinnis \& Michael B. Rappaport, Originalism and the Good Constitution 117 (2013) (developing "original methods originalism" through discussion of "strong evidence that the original interpretive rules were essentially originalist in that they tried to discover the meaning of a provision at the time of its enactment").

271 Wilkinson, supra note 4 , at 46.

272 Wilkinson, supra note 91, at 256.

273 See, e.g., Keith E. Whittington, The New Originalism, 2 GEO. J.L. \& Pub. Pol'y 599, 608 (2004) (contrasting "the new originalism" with "old originalism" on the ground that " $[t]$ he new originalism is less likely to emphasize a primary commitment to judicial restraint .... $[\mathrm{T}]$ here seems to be less emphasis on the capacity of originalism to limit the discretion of the judge."). 
being offered as contributions to originalism (or anti-originalism) scholarship. But they are not best understood as offered in that spirit and their value lies elsewhere. Their criticisms of originalism and their injunctions to pragmatic and restrained adjudication are complaints about the ways in which they believe that Justice Scalia's opinion fails to display certain qualities of judicial excellence-qualities that pragmatism and restraint foster in the disposition of the good judge.

That they are offering dispositional accounts of the judicial office and judicial excellence rather than theories of interpretation or adjudication hardly means, however, that their views are immune from criticism. To the contrary, much can be said about the nature of judicial excellence and the character of mind that represents judging at its best. Indeed, once judicial pragmatism and judicial restraint are understood for what they truly arejudicial dispositions or qualities of mind-a different angle of criticism becomes apparent. This criticism focuses not on constitutional theory, but on the adequacy and depth of their accounts of good judging. It takes on, and takes issue with, their portraits of judicial greatness.

Consider again Judge Posner's criticism that Heller exemplifies a more general originalist "disregard for the interpretive conventions of the legal culture in which the Second Amendment was drafted and ratified." 274 We are now assessing this claim not as a statement of originalism's flaws qua interpretive theory, but as an exercise in intellectual history-as a description of the dispositions and qualities of mind of good judging in the late eighteenth and early nineteenth century. And note further that to support his point about what these conventions actually consist of, Posner refers back not to a theory of constitutional interpretation but to a historical figure-indeed, to a specific judge, Chief Justice John Marshall. ${ }^{275}$ Indeed, both Posner and Wilkinson often speak in terms of "schools," not theories, of judging ${ }^{276}$ another indication that their primary focus is on dispositional or characterological qualities.

Yet taken in these terms, Posner's claim is highly contestable as a statement of Marshall's disposition toward the judicial office. Posner's view is not based on a comprehensive historical study of late eighteenth-century and early nineteenth-century interpretive conventions, but on a contested account of Marshall's approach to constitutional interpretation as a "loose . . construction[ist]." 277 Posner cites a smattering of judicial opinions, Madison's Federalist No. 37, a law review article on the early American judicial power by William Eskridge, and essays on Marshall by James Bradley Thayer, Oliver Wendell Holmes, and Felix Frankfurter. ${ }^{278}$ To be sure, these all support Posner's claim about Marshall and loose construction. But in his eagerness to claim Marshall for pragmatism, Posner leaves out, among other

274 PosNer, supra note 13, at 193.

275 Id.

276 Id. at 155; see also Wilkinson, supra note 58, at 802.

277 Posner, supra note 13 , at 193 \& 193 n.40.

278 Id. 
things, reference to more detailed accounts of Marshall's jurisprudence in constitutional cases, ${ }^{279}$ scholarly accounts of Madison's understanding of the judicial power, ${ }^{280}$ John Manning's counterpoint to Eskridge's article, ${ }^{281}$ and more recent scholarly explorations of Marshall's thought that provide important historiographical and jurisprudential perspective on Thayer's, Holmes's, and Frankfurter's appropriation of Marshall. ${ }^{282}$ A fuller portrait of Marshall's approach to constitutional adjudication looks very different from the "loose constructionist" sketched by Posner. ${ }^{283}$ In fact, the Marshallian ideal invoked by Posner is largely a product of twentieth-century mythmaking. ${ }^{284}$

Yet the point is not simply, or even primarily, to criticize Posner's description of Marshall as a "loose constructionist." It is to dispute crucial features of the portrait of judicial excellence that emerge from this account-features which are also on display in Posner's writing at rest but which are greatly muted in Posner's writing at work (in that relatively small percentage of decisions in which judicial pragmatism is detectable at all). Marshall the "loose constructionist" is no more accurate a description of Marshall the judge than is Posner the "judicial pragmatist" an accurate description of Posner the judge. In Posner's writing at rest, the extent to which law is said to constrain and inform Marshallian and Posnerian judgment is minimized or glossed over in the process of sketching a distorted portrait of judicial excellence that overemphasizes the "coping strategies" 285 judges employ in order to compensate for the purported absence of law. In his writing at

279 For an account of Chief Justice Marshall's commitment to what is now denominated originalist reasoning, see Gary L. MCDowell, The Language of Law and the Foundations of American Constitutionalism 311-40 (2010). This is the bulk of chapter seven of Professor McDowell's book, a chapter titled "The Most Sacred Rule of Interpretation: John Marshall, Originalism, and the Limits of Judicial Power." For an explanation of the sincerity of, and legal background behind, Marshall's assertion in Osborn v. Bank of the United States that "[c] ourts are the mere instruments of the law, and can will nothing," 22 U.S. (9 Wheat.) 738, 866 (1824), see Charles F. Hobson, The Great Chief Justice: John Marshall and the Rule of Law 136-39 (1996).

280 See Jack N. Rakove, Judicial Power in the Constitutional Theory of James Madison, 43 WM. \& Mary L. Rev. 1513 (2002).

281 See John F. Manning, Deriving Rules of Statutory Interpretation from the Constitution, 101 Colum. L. Rev. 1648 (2001).

282 See R. Kent Newmyer, John Marshall and the Heroic Age of the Supreme Court 466-79 (2001) (providing an historical account of the development of " $[\mathrm{t}]$ he Marshall Myth and the Modern Nation-State"); see also Robert Kenneth Faulkner, The JurispruDENCE OF John Marshall app. at 227 (1968) (providing a detailed analysis of Justice Holmes's account of Chief Justice Marshall); id. at 228 (concluding "that we have been misled about the quality and character of the country's original jurisprudence"). Posner's description of Marshall as an ancestor of Thayer and a "loose constructionist" derives from Holmes's famous address on the one hundredth anniversary of Chief Justice Marshall's accession to the bench. See Oliner Wendell Holmes, Collected Legal Papers 266-71 (1920). The characterization is later picked up by Alexander Bickel in his discussion of Thayer. See Alexander M. Bickel, The Least Dangerous Branch 36 (1962).

283 See supra note 282 and accompanying text.

284 See Newmyer, supra note 282, at 473-79.

285 Posner, supra note 13, at 149-235. 
work-even in those constitutional cases where coping strategies might seem most needed-it is neither judicial pragmatism nor loose constructionism that often plays the decisive role. ${ }^{286}$

Judge Posner would surely deny or deflect this criticism. He has argued that judicial pragmatism encompasses structural and hierarchical limits on judicial decisionmaking, just as it incorporates textual and historical considerations under the right circumstances, and just as it takes appropriately seriously the value of precedential constraint. Judicial pragmatism may implement these features of adjudication for merely tactical reasons, but it does implement them. ${ }^{287}$ Judicial pragmatism adopts whatever is good and useful from legalistic methodology, discarding the rest. Posner would therefore contest the claim that his decisions are not simultaneously thoroughly pragmatic and eminently law-like. Indeed, for Posner, the decision of a pragmatic judge acting within his authority just exactly is the law: "Judicial role' is another name for the judge's jurisdiction,"288 and "whatever judges do within their jurisdiction is law." 289

Yet this denial only serves to underscore the inadequacy of judicial pragmatism as a guide for constitutional adjudication. Judge Posner may insist that judicial pragmatism integrates the very judicial methodologies that he has spent decades attacking extrajudicially, and he may be compelled to do so in order to explain and justify the sorts of legally constrained decisions that he himself has reached in the constitutional cases discussed in Part II. But he thereby makes plain that judicial pragmatism neither can serve nor is actually intended as a theoretical upgrade from legalism, or originalism, or any other constitutional theory. Judicial pragmatism simply changes the subject; and in changing the subject, it paints a portrait of judicial excellence that at best imperfectly, and at worst inaccurately, reflects even his own constitutional adjudication.

The same genre of criticisms applies to Judge Wilkinson's depiction of judicial restraint, and to the historical figures whom he associates with judicial greatness. For Wilkinson, judicial restraint is the label for a series of "mundane and humdrum truths" 290 that point backward toward "the values of traditional adjudication." 291 "[W]isdom," he writes, "lies simply in know-

286 This observation dovetails with a similar observation made by John Manning in an essay on Posner's approach to statutory interpretation. John F. Manning, Statutory Pragmatism and Constitutional Structure, 120 HARv. L. REv. 1161 (2007). Manning distinguishes between the debate over "how a judge should read statutes in general" from the debate over "how a judge should read statutes given the frame of reference supplied by our constitutional structure." Id. at 1174. The contribution of Posner's implicit or tacit sense of constitutional structure "at work" explains why his judicial output does not resemble what one might expect based solely on his "at rest" account of pragmatic adjudication.

287 Posner, LAw, supra note 40, at 63.

288 Id. at 267.

289 Posner, supra note 13, at 130.

290 Wilkinson, supra note 4, at 116.

291 Id. at 80. 
ing the limits of one's knowledge," and this wisdom has been neglected, or forgotten, by the proponents of cosmic constitutional theory. ${ }^{292}$

Yet in Wilkinson's account, the values of traditional adjudication were only given their canonical formulation in the late nineteenth-century writing of James Bradley Thayer. And many of Wilkinson's heroes of judicial restraint-Justice Holmes, Justice Frankfurter, and Justice Lewis Powell, for example-either profoundly influenced or were themselves influenced by the legal realism that emerged in subsequent decades. Indeed, judged as a historical phenomenon, there is nothing timeless or particularly shopworn about judicial restraint. Judicial restraint in the hands of Thayer was a strategic reaction to the burgeoning challenge of legal indeterminacy that would come to a head in the legal realist and critical legal studies periods just a few decades later.

Viewed in this historical light, Thayerian judicial restraint does not sit outside the cosmic theories that Wilkinson criticizes. It does not, as Posner believes, precede the rise of constitutional theory. ${ }^{293}$ Thayer's judicial restraint is the very first cosmic constitutional theory. It is "cosmic" precisely inasmuch as it was offered as an ersatz version of the truly cosmic view of law that long held sway before it-the understanding of law as a locus of transtemporal, transcendent truth with its own internal logic. ${ }^{294}$ Thayer meant to replace preemptively what later writers have denounced as "transcendental nonsense"295 - the ancient and metaphysically robust view of law that was already under siege at the time Thayer wrote. That Holmes should be a hero to Wilkinson is puzzling, since it was Holmes who vigorously and cheerfully heralded the impending demise of the traditional view of law and judging during that same period. ${ }^{296}$

The particular challenge that Thayer confronted was the constitutional function of the judge in a late nineteenth-century world in which law's own cosmic foundations had begun to crumble. Unlike Wilkinsonian judicial restraint, Thayerian judicial restraint is a cosmic theory because it offers a single, stable, guiding precept of constitutional adjudication-Thayer's "rule of administration"- to the judge in the post-lapsarian legal universe: judges

\footnotetext{
$292 I d$. at xii (ed. note).

293 Posner, supra note 13, at 166.

294 See Steven D. Smith, "Hollow Men"? Law and the Declension of Belief, in Civilizing Authority 197, 206 (Patrick McKinley Brennan ed., 2007) ("For centuries, it was a common view among Western legal thinkers that law was a manifestation of something that transcended mundane human enactments and human decisions."); see also Swift v. Tyson, 41 U.S. (16 Pet.) 1, 18 (1842) ("[I]t will hardly be contended that the decisions of Courts constitute laws. They are, at most, only evidence of what the laws are; and are not of themselves laws."); Harold J. Berman, Law and Revolution: The Formation of the Western Legal Tradition 38-39 (1983) (discussing the disintegration of "[ $\mathrm{t}$ ] he old metalaw" as a way of giving coherence to the Western legal tradition).
}

295 Felix S. Cohen, Transcendental Nonsense and the Functional Approach, 35 Colum. L. Rev. 809, 811 (1935).

296 See generally Oliver Wendell Holmes, Jr., The Path of the Law, 10 Harv. L. Rev. 457 (1897). 
"can only disregard [an] Act when those who have the right to make laws have not merely made a mistake, but have made a very clear one,- - so clear that it is not open to rational question." 297 True, Thayer purported to locate this rule in a rather slapdash American history of judicial review that suited his theoretical purposes, but no court had ever before offered up a single guiding precept of constitutional adjudication in the way Thayer did. There was no need for a theory of judicial review when law was itself understood to structure and set limits on a judge's office. ${ }^{298}$

Once Thayer's fixed principle of judicial restraint is understood not as a distillation of timeless, commonsense judicial wisdom but as a historically specific rearguard reaction in the early phases of constitutional theory's ascendancy, the flaws in Wilkinson's portrait of judicial excellence become clearer. Wilkinson's judicial heroes are all inheritors of Thayer's apologetic project; and with each adaptation of judicial restraint in their hands, judicial restraint's impotence to replace the truly cosmic understanding of law became plainer. Holmes's famously skeptical pronouncement that " $[\mathrm{y}] \mathrm{ou}$ can give any conclusion a logical form" 299 is genealogically connected to Thayerian restraint: both are expressions of proto-realism, and Holmes's position provides a vital premise for adhering strictly to Thayer's rule of administration. If "any" conclusion may be given a legal form, the crucial issue is neither the law nor the conclusion, but the authority of the person making law and reaching conclusions. Thayer's restraint is a judicial defense mechanism against what he perceived as the "inescapably political" quality of law. ${ }^{300}$

Thayer's influence on Frankfurter has been remarked before, ${ }^{301}$ but Frankfurter's adherence to judicial restraint was again a historically specific defensive action against the perceived antiprogressive and antidemocratic intrusiveness and obstructionism of the pre-1937 New Deal Court. Upon his appointment in 1939, Frankfurter, drawing on Holmes and Thayer before

297 James Bradley Thayer, The Origin and Scope of the American Doctrine of ConSTITUTIONAL LAW 18 (1893).

298 See Philip Hamburger, Law and Judicial Duty 18 (2008) (arguing that in the history of constitutionalism before the advent of "judicial review," "[i]t was widely assumed that human law existed within a hierarchy that reached from God down to man and that therefore even human law had a divinely derived obligation"); see also id. at 309 (discussing a statute's "manifest contradiction" with the Constitution not as implicating merely a judicial " "rule of administration'" like Thayer's, but as instead generating a judicial duty that "arose from the obligation of law in conscience").

299 Holmes, supra note 296, at 466.

300 PosNer, supra note 13, at 154.

301 Bickel, supra note 282, at 35; see also Brad Snyder, Frankfurter and Popular Constitutionalism, 47 U.C. DAvis L. REv. 343, 354-55 (2013). Frankfurter's description of Thayer's Origin and Scope article is revealing inasmuch as he himself takes it to offer something very similar to a constitutional theory: " $[\mathrm{F}]$ rom my point of view it's the great guide for judges and therefore, the great guide for understanding by non-judges of what the place of the judiciary is in relation to constitutional questions." Felix Frankfurter, Felix Frankfurter Reminisces 300 (Harlan B. Philips ed., 1960). 
him, could expound a general jurisprudence of judicial review that also suited his political inclinations. His veneration of Holmesian restraint took shape against the backdrop of resisting the judicial conservatism that had deployed substantive due process and ideas of freedom of contract to defeat what Frankfurter believed was socially important economic legislation. ${ }^{302}$

One historian has described " $[\mathrm{t}]$ he tragedy of Mr. Justice Frankfurter" as the vice of becoming "prisoner [to] an idea-judicial restraint," ${ }^{03}$ one which eventually led Frankfurter to well-documented defeats in the aftermath of Minersville School District v. Gobitis. ${ }^{304}$ Yet the tragedy was not Frankfurter's, but judicial restraint's. Frankfurter's error was not in pledging allegiance to an idea, but to the wrong idea. Frankfurter's defeat was borne from judicial restraint's inability to bear the cosmic burden laid on it by its champions in response to the realist challenge, a failure that had been in evidence since well before Frankfurter's time. And this is precisely the problem for Judge Wilkinson's school of judicial restraint: it is a school whose notions of judicial excellence depended on an idea that had no persuasive responses to the problematics of constitutional adjudication in the twentieth century. ${ }^{305}$

\section{Judge Friendly's View of Judicial Excellence}

In keeping with the move from theory to disposition, and with the judges' emphasis on judicial exemplars, we suggest that in the post-legal realist twentieth century, Judge Henry Friendly's view of constitutional theory and his understanding of judicial excellence provide a more appealing (even if more impressionistic) portrait of judicial excellence than those sketched by Judge Posner and Judge Wilkinson. Friendly, who sat on the Second Circuit from 1959 to 1986 and is regarded by some as "the greatest judge of his

302 See Melvin I. Urofsky, Conflict Among the Brethren: Felix Frankfurter, William O. Douglas and the Clash of Personalities and Philosophies on the United States Supreme Court, 1988 Duke L.J. 71, 81-82.

303 Id. at 95 .

304310 U.S. 586 (1940).

305 Snyder interprets Frankfurter's judicial restraint as an early example of popular constitutionalism. Snyder, supra note 301, at 350. He also claims that Frankfurter favored departmentalism. Id. at 351. If that is the correct view of Frankfurter's jurisprudence, three further problems emerge. First, it is doubtful that Wilkinson would continue to claim Frankfurter as a judicial role model. Wilkinson's jurisprudence is not that of popular constitutionalism. Second, if Frankfurter favored both popular constitutionalism and departmentalism, his position seems in tension with itself. Popular constitutionalism places authority in the people's hands; departmentalism places authority in the hands of the legislative, executive, and judicial departments. Third, popular constitutionalism is, to date, largely an academic phenomenon. It has had no perceptible influence on the federal judiciary. This is not the place to discuss its own failings. See Lawrence B. Solum \& Larry Alexander, Popular? Constitutionalism?, 118 Harv. L. Rev. 1594 (2005) (reviewing Larry D. Kramer, The People Themselves: Popular Constitutionalism and Judicial Review (2004)). Suffice it to say, however, that it cannot bear the cosmic burden either: the people themselves seem quite content with a powerful judiciary. 
era," 306 was conversant with contemporary debates in legal theory. And like Posner and Wilkinson, Friendly, too, wrote extrajudicially on a range of issues. ${ }^{307}$ Yet an important contrast between Posner and Wilkinson, on the one hand, and Friendly, on the other, is that Friendly did not attempt to place a theoretical umbrella over or assign a label to his approach to judging.

Posner has claimed Friendly for judicial pragmatism, ${ }^{308}$ and one can easily imagine Wilkinson drawing on Friendly's decisions in constitutional cases to claim him for judicial restraint. Yet Friendly himself steadfastly avoided affixing any label to his approach to adjudication. ${ }^{309}$ Guided by his example, we consider Friendly's stance toward academic theory on its own terms. For even as Friendly distanced himself from the enterprise of academic theorizing about adjudication, his extrajudicial writing can help us better understand the scope and limits of such theorizing. In particular, we consider here how Friendly's extrajudicial writings underwrite an internal critique and an external critique of an emblematic example of constitutional theory-Professor Ronald Dworkin's theory of law as integrity.

In 1975, the Harvard Law Review published Dworkin's famous article, Hard Cases, in which he took up a debate with H.L.A. Hart over the exercise of judicial discretion in cases of legal indeterminacy. ${ }^{310}$ As summarized by Friendly, Hart understood judges to "exercise a 'legislative' discretion in which policy considerations may be taken into account," while Dworkin argued that "the judge may rely on a newly discovered but nevertheless preexisting 'principle' . . . but not on considerations of 'policy." "311 But Friendly declined to engage in this dispute. He tried to "remain aloof" from the debate, noting its vigor and length as well as his "own deficiencies": "In jurisprudential controversies of this sort I tend to agree with whomever I have read last." 312

Judge Friendly's demurral is hard to credit. He did not shy away from other vigorous, long-standing debates and he was obviously intellectually able enough to participate. More probably, he simply believed that the debate did not matter to judges: "[I] $\mathrm{t}$ is not clear to me how far apart, in any practi-

306 See David M. Dorsen, Henry Friendly (2012).

307 For a full listing of Friendly's extrajudicial writings, see id. app. B at 367-70.

308 Posner and Friendly enjoyed a warm and substantial correspondence when Posner became a judge, meeting on several occasions. See William Domnarski, The Correspondence of Henry Friendly and Richard A. Posner 1982-86, 51 Am. J. Legal Hist. 395 (2011).

309 Perhaps this is in part explained by the fact that before becoming a judge, Friendly was in private practice, while Posner and Wilkinson were both in the legal academy. Although Friendly himself avoided adopting a label, Judge Posner is not alone in describing Friendly as a pragmatist. See Daniel L. Breen, Henry J. Friendly and the Pragmatic Tradition in American Law 14-18 (Nov. 22, 2002) (unpublished Ph.D. dissertation, Boston College) (on file with author) (depicting Friendly as an exemplar of American judicial pragmatism).

310 See Ronald Dworkin, Hard Cases, 88 Harv. L. Rev. 1057 (1975).

311 Henry J. Friendly, The Courts and Social Policy: Substance and Procedure, 33 U. Miami L. REv. 21, 24 n.14 (1978).

312 Id. 
cally significant sense, the disputants really are."313 In the words of Edmund Ursin, "Friendly's view was that Dworkin's jurisprudence (and, of course, that of those who would follow his lead and pursue abstract theorizing) would be of little use to those concerned with how judges actually decide cases." 114

The influence of day-to-day considerations on Judge Friendly's perspective as an intermediate appellate judge explains the remoteness of Friendly's concerns from Dworkin's. Had Dworkin addressed Friendly, ${ }^{315}$ he likely would have argued that "law as integrity"-which requires judges to combine the dimensions of "fit" and "justification"316_accounts for the particular obligations and functions that a hierarchical system imposes on a judge. But the idea that judges bring to constitutional adjudication a distinctive perspective that arises out of their particular role within the judicial hierarchy issues in both an internal and an external critique of Dworkin's theory.

The internal critique focuses on the need to account for judicial role as an element either of "fit" or "justification." Dworkin's beau ideal is Hercules, "an imaginary judge of superhuman intellectual power and patience who accepts law as integrity" and its demands of fit and justification. ${ }^{317}$ It matters not to Dworkin's theory just what court Hercules sits on. ${ }^{318}$ This is a problem for a theory in which judicial role is a component either of fit or justification. All federal judges exercise the "judicial power" vested in them by Article III, but each judge's role depends in part on where he or she sits in the hierarchy. The roles of district court judges, circuit court judges, and Supreme Court Justices are not the same. Dworkin describes "fit" as a "threshold" issue for all judges, but he also acknowledges that after an interpretation passes

313 Id. (emphasis added). Friendly nevertheless made clear that he sided with Hart over Dworkin, describing the move to strict products liability as resting on judicial considerations of policy and criticizing Dworkin for trying to recast the move as one based on principle. See id. at 27 n.30.

314 Edmund Ursin, How Great Judges Think: Judges Richard Posner, Henry Friendly, and Roger Traynor on Judicial Lawmaking, 57 BufF. L. REv. 1267, 1349 (2009).

315 As far as we are aware, Dworkin never wrote about Friendly.

316 Judgments of "fit" provide a "rough threshold requirement that an interpretation of some part of the law must meet if it is to be eligible at all." Judgments of justification occur when the "threshold test" of fit "does not discriminate between two or more interpretations" of the law, and in which a judge "must choose between eligible interpretations by asking which shows the community's structure of institutions and decisions-its public standards as a whole-in a better light from the standpoint of political morality." Judgments of justification thus assume cardinal importance in hard cases. RONALD DwORKIN, LAW's EMPIRE 255-56 (1986).

317 Id. at 239; see also Dworkin, supra note 310, at 1083.

318 When Dworkin first introduces him in Hard Cases, Hercules is "a judge in some representative American jurisdiction," Dworkin, supra note 320, at 1083, where he may still be found at the beginning of Law's Empire. In a chapter toward the end of Law's Empire discussing "The Constitution," Dworkin imagines that "Hercules is promoted" to the Supreme Court ("Olympus"), where Dworkin has him consider various cases dealing with racial equality. Dworkin, supra note 316 , at 379 . Yet there is virtually no difference between the duties of Justice Hercules and Judge Hercules, no change in their respective obligations. 
that "threshold," "any infelicities of fit will count against it . . . in the general balance of political virtues." 119 Even assuming that "the general balance of political virtues"320 supplies a coherent criterion, however, the balance should be struck differently at different levels of the federal judicial hierarchy-precisely because of variations in judicial role. A district court judge deciding an issue of first impression in a case that is sure to be appealed, for example, should weigh fit more heavily than should a higher court. ${ }^{321}$ The point is not simply that Hercules has a judicial "view from nowhere," but that a judicial view from nowhere cannot serve as an ideal for any judge. Judges always sit somewhere. ${ }^{322}$

An external critique of Dworkin emerges in Judge Friendly's entirely different perspective on judicial excellence. In Reactions of a Lawyer-Newly Become Judge, Friendly described some of the specialized skills of the appellate judge, qualities that develop from the "grist of an appellate court"-the vast majority of cases that comprise the appellate docket, in which either "the law and its application alike are plain" " or " the rule of law is certain, and the application alone doubtful." "323 In the course of deciding these cases, the generalist judge acquires a "specialized competence" by "sharpening his skills on a variety of grindstones." 324 Friendly's description of these skills is worth quoting at length:

He will have acquired the power of analysis, of determining the issuesoften quite other than what the parties think these to be. He will have learned to heed the imperative of going to the sources; experience will have taught him, if wisdom has not, never to rely on a characterization or on memory of what a witness has testified, a document stated, an opinion ruled, a statute commanded. He knows how to find these sources with speed and accuracy, and how to deal with them once they have been found. He understands how to pick evidence apart, to determine the inferences that may reasonably be drawn, to weigh one piece of testimony against another. He will have acquired some skill in the understanding of decisions and their precedential value; he will have learned something also about the reading of

319 Dworkin, supra note 316, at 256. This part of the book is quoted in John M. Finnis, On Reason and Authority in Law's Empire, 6 Law \& PHIL. 357, 374 (1987) available at http:// scholarship.law.nd.edu/law_faculty_scholarship/677.

320 DWORKIN, supra note 316, at 256.

321 Cf. Virginia ex rel. Cuccinelli v. Sebelius, 728 F. Supp. 2d 768, 790 (E.D. Va. 2010), vacated, 656 F.3d 253 (4th Cir. 2011) ("This case . . turns on atypical and uncharted applications of constitutional law interwoven with subtle political undercurrents. The outcome of this case has significant public policy implications. And the final word will undoubtedly reside with a higher court.").

322 This criticism is not to be confused with the claim that Hercules is an unhelpful model because no judge has his superhuman powers or his freedom from "the press of time and docket." DwORKIN, supra note 316 , at 380 . Bracketing certain human constraints and practical issues is one way to formulate an ideal approach to judging. But certain institution-specific considerations such as judicial role are not bracketable.

323 Henry J. Friendly, Reactions of a Lawyer-Newly Become Judge, 71 YALE L.J. 218, 222 (1961) (quoting Benjamin N. Cardozo, The Nature of the Judicial Process 164 (1921)). 324 Id. at 223. 
statutes. He will have trained himself to test his conclusions by essaying to put them in writing, and to express them fairly, clearly, and cogently. ${ }^{325}$

Friendly's views have been echoed by other judges. ${ }^{326}$ And Friendly's use of the passive voice in describing the acquisition of some of these skills captures a feature of judging within a hierarchical system often underappreciated by academic theorists. The enterprise is not simply one in which a judge works upon cases, but also one in which the cases work upon the judge. ${ }^{327}$

In light of Judge Friendly's view of judicial excellence, it is not surprising that he would be uninterested in engaging the work of a theorist who aimed to expose "the hidden structure of [real judges'] judgments" as "if they had a career to devote to a single decision." 328 Friendly did not criticize Dworkin for imagining the god-like Hercules as his model judge. He did not comment on Hercules at all. But another distinguished federal appellate judge, senior Ninth Circuit Judge John T. Noonan, Jr., did. Noonan observed that Hercules resembles a law professor more than a judge: ${ }^{329}$ "[T] he decision of cases affecting real people demands a sensitivity that handling hypothetical ones does not." 330 The proper exercise of judicial discretion requires, he wrote, an element of practical wisdom that is not "captured in any of Mr. Dworkin's formulations." 331 Instead, this practical wisdom is cultivated by a sensitivity to real people that "is nurtured by experience" and "eventuates in ... prudence."332

\section{Id. at 222.}

326 See, e.g., Michael Boudin, Judge Henry Friendly and the Craft of Judging, 159 U. PA. L. REv. 1, 2, 14 (2010) (describing Friendly's opinions as "the gold standard in American appellate judging" and asserting that "Friendly's way of judging has a timeless attraction: the predicate mastery of precedent and record; a care alike for doctrine and for equity and for social need; the reasoned and candid explanation of the result; and an awareness always of the comparative competencies and limits of judges"); Richard A. Posner, Will the Federal Courts of Appeals Survive Until 1984? An Essay on Delegation and Specialization of the Judicial Function, 56 S. CAL. L. REv. 761, 779 (1983) (describing "a skill at judging that comes from long practice in evaluating arguments of counsel, decisions of trial judges, and trial records and that is a legitimate fruit of specialization in the function of appellate judging"); J. Harvie Wilkinson, III, If It Ain't Broke . . ., 119 Yale L.J. OnLIne 67 (2010), available at http://yalelawjournal.org/pdf/840_egpccc2c.pdf.

327 Cf. Walton H. Hamilton, Judicial Process, in 4 Encyc. of THE Soc. Scr. 450 (Edwin R.A. Seligman \& Alvin Johnson eds., 1932) ("In the instance the suits are controlled by the rules; in the aggregate the rules are determined by the suits."). The idea that time spent as a judge leaves its mark on the individual holding judicial office can be seen in the title of Friendly's book of collected essays. Henry J. Friendly, Benchmarks (1967).

328 Dworkin, supra note 316, at 265.

329 Noonan does not intend this as an insult, for he was a full-time law professor himself before he was appointed to the bench.

330 John T. Noonan, Jr., Hercules and the Snail Darter, N.Y. Times, May 25, 1986, http:// www.nytimes.com/1986/05/25/books/hercules-and-the-snail-darter.html.

$331 \quad I d$.

$332 I d$. 
Judge Friendly would have agreed with Judge Noonan, for he much preferred Judge Learned Hand to Dworkin's learned Judge Hercules. ${ }^{333}$ Of the judges Friendly identified as great, Hand was "the only one who served as a federal circuit judge and not on a court of last resort." 334 Friendly admired Hand less for decisions in "the few great cases that inevitably came to him over the years" than for "the great way in which he dealt with a multitude of little cases, covering almost every subject in the legal lexicon. Repeatedly he would make the tiniest glowworm illumine a whole field." ${ }^{335}$ By contrast, Dworkin, who served as a law clerk for Hand, wrote in highly qualified and comparatively negative terms about Hand's view of constitutional adjudication (he wrote warmly of Hand himself). In a late chapter of Freedom's Law, Dworkin criticizes Hand's extreme and "austere view" that "there was no warrant in the Constitution for judges having any power to invalidate the acts of another 'department' of government." 336 Likewise, Dworkin rebuffed Hand's warning about rule by philosopher-judges as "a piece of hyperbole."337

Yet Dworkin was not indifferent or insensitive to the actual lived experience, insights, and perceptions of judges like Friendly. He developed Hercules in part to account for the phenomenon that "when good judges try to explain in some general way how they work, they search for figures of speech to describe the constraints they feel even when they suppose that they are making new law, constraints that would not be appropriate if they were legislators."338 Judges say, for example, "that they find new rules imminent [sic] in the law as a whole" or "that the law has some life of its own even though this belongs to experience rather than logic."339 Dworkin views these statements as signposts to guide Hercules in his quest for law as integrity. "Hercules must not rest content with these famous metaphors and personifications, but he must also not be content with any description of the judicial process that ignores their appeal to the best lawyers." 340 These signposts matter from Friendly's perspective as well, but they point in a different direction. From his perspective, attention to what "good judges" say extrajudicially when they "try to explain in some general way how they work," and also to what they do when they engage in the activity of judging itself, highlights the need for

333 Friendly's biographer, David Dorsen, reports that Friendly's "favorite judge was Learned Hand." Dorsen, supra note 306, at 123.

$334 I d$.

335 FriendLy, supra note 327, at 315.

336 Ronald Dworkin, Freedom's Law 339 (1996); see also id. at 341-42 ("Hand's skepticism consisted not in the philosophical view that no moral conviction can be objectively true, but in a disabling uncertainty that he-or anyone else-could discover which convictions were true."). Dworkin tried to reconcile his views with Hand's in this chapter but the differences in their respective approaches to adjudication are striking. See Noah R. Feldman, Unresolved Tensions, 106 YALE L.J. 229, 234 (1996) (reviewing Dworkin, supra).

337 Ronald Dworkin, A Matter of Principle 71 (1985).

338 Dworkin, supra note 310, at 1090.

339 Id.

$340 \mathrm{Id}$. 
deeper and closer investigation of judicial excellence from their internal point of view. ${ }^{341}$

The point of view Judge Posner adopts in his most recent book-Reflections on Judging - is exemplary in this regard. ${ }^{342}$ And his defense of Friendly in that book against Professor Adrian Vermeule's assessment that "Friendly's contribution was not to enrich the theory of the law but to provide a living model of lawyerly craft and good judgment" is illuminating. ${ }^{343}$ Contending that "Vermeule's assessment underrates Friendly," Posner writes that " $[\mathrm{m}]$ any of Friendly's ideas, expressed either in his opinions or in his very influential nonjudicial writings, were adopted by the Supreme Court, which having done so got the credit for them." ${ }^{444}$ Yet this response does not directly counter Vermeule's assessment; that the Supreme Court's adopted many of Friendly's ideas does not show that Friendly enriched legal theory, but that his hierarchical superiors valued those ideas as products of lawyerly craft and good judgment. To show that Vermeule underrates Friendly, one would need to argue instead that Vermeule underrates the lawyerly craft and good judgment that he and others see in Friendly. Evidence that he may do so appears in Vermeule's formulation of "[t]he puzzle" about Friendly, namely that he was brilliant and is lauded by prominent "hagiographers and celebrants," but "it is actually a bit difficult to say what Friendly stood for, or what ideas of general and lasting significance he contributed to law and legal theory." 345 This is only a puzzle, of course, if one expects that a brilliant judge should be expected to contribute "ideas of general and lasting significance ... to law and legal theory." 346

Vermeule may be right that "the reputations of judges such as Friendly generally have a shorter half-life than the reputations of judges who offer fertile theoretical ideas that can be distilled into formulas, theorems, and pithy aphorisms." 347 But if he is right, it may well be because of the peculiar

\section{$341 \quad I d$.}

342 Posner, supra note 13. But cf. Kevin C. Walsh, Posner on Realist Judging, JOTWELL, (Dec. 10, 2013), http://courtslaw.jotwell.com/posner-on-realist-judging/ (contending that the book's chapters addressing theories of judicial restraint and interpretation "fit uneasily into the book because Posner's reduction of these ideas to judicial attempts to escape from complexity are unconvincing").

343 Adrian Vermeule, Local Wisdom, The New Republic (Mar. 22, 2012), http://www .newrepublic.com/book/review/henry-friendly-supreme-court-david-dorsen (review of Dorsen, supra note 306).

344 Posner, supra note 13, at 356.

345 Vermeule, supra note 343.

$346 I d$. Later in the review, Vermeule remains uncommitted in the "eternal competition between different models of what counts as good judging." Id. In an earlier work, Vermeule advocates "for both statutes and the Constitution, an interpretive decision-procedure that leaves little room for judicial creativity, for the aesthetic rigors and rewards of lawyerly guild-craft in its more baroque forms, and for the elaborate study of Supreme Court decisionmaking.” Adrian Vermeule, Judging Under Uncertainty 285 (2006).

347 Vermeule, supra note 343. 
reputational preoccupations of the legal academy, where theoretical sophistication, even in judges, is more highly valued than good judgment. ${ }^{348}$

\section{Conclusion}

Nearly two centuries ago, the judge-scholar Justice Joseph Story criticized "collateral interpretation" of the Constitution derived from "theory" and praised "the practical exposition of the government itself in its various departments" for its resemblance to judicial exposition. ${ }^{349}$ Story was not indulging in anti-intellectual peevishness. He was marking the difference between constitutional theory in vacuo and constitutional exposition in a specific public, practical setting-the setting of the judicial office: "How light, compared with these means of instruction, are the private lucubrations of the closet, or the retired speculations of ingenious minds, intent on theory, or general views, and unused to encounter a practical difficulty at every step!"350 What Justice Story had in mind was not a theory, but the disposition of judicial excellence. We have suggested that the same is true of Judge Posner and Judge Wilkinson.

Despite the occasional packaging, the critique of constitutional theory offered by Judges Posner and Wilkinson as well as their own approaches are not best understood as rivals to or replacements of existing constitutional theory at all. When they write extrajudicially about constitutional law, they are not dogs walking on their hind legs. They walk on all fours in developing their own accounts of the good judge at work in constitutional cases. And the insights derived from these accounts illuminate the need for further reflection on the nature of judicial role and judicial duty within the American constitutional system. Their extrajudicial writings point toward the utility of sources of nontheoretical insight into adjudication, including critical judicial biographies, intellectual judicial histories, and other work in which judges engage in self-reflection and situate their own thought in relation to their peers, past and present.

Most especially, however, the dimensions of judicial role and judicial excellence examined in this Article call for renewed attention to that most conventional source of insight about adjudication: judicial opinions. Doctrinal mastery was once the primary function of legal academics. Doctrine's fall from academic grace may exacerbate the sense-perhaps it exacerbated Chief Justice Roberts's sense-that the practice of law is one thing, its academic study another. It is no doubt true that these are different activities with different aims. But to the extent that academic work in constitutional law may be useful for constitutional adjudication, this Article suggests that a focus on the ways in which academic ideas about constitutional law translate into actual opinions and doctrine is imperative. The best understanding of

348 Boudin, supra note 326.

349 Joseph Story, Commentaries on the Constitution of the United States $§ 408$ (1833).

$350 \mathrm{Id}$. 
judicial role and duty does not sit outside constitutional decisionmaking, but instead emerges from careful and sustained attention to the practice of constitutional judging itself. 
